\title{
SYNTHESES OF 9-SUBSTITUTED JOSAMYCIN, 13-SUBSTITUTED ISOJOSAMYCIN AND THEIR TETRAHYDRO DERIVATIVES
}

\author{
Akiniro Tanaka, Azuma Watanabe*, Reiko Kobayashi, Tsutomu Tsuchiya, \\ Sumio Umezawa, Masa Hamada** and Hamao Umezawa** \\ Institute of Bioorganic Chemistry, 1614 Ida, Nakahara-ku, Kawasaki 211, Japan \\ *Department of Applied Chemistry, Faculty of Engineering, Keio University, \\ Hiyoshi, Kohoku-ku, Yokohama 223, Japan \\ **Institute of Microbial Chemistry, 14-23 Kamiosaki 3-Chome, \\ Shinagawa-ku, Tokyo 141, Japan
}

(Received for publication May 14, 1981)

\begin{abstract}
Derivatives of josamycin and isojosamycin modified at C-9 and C-13 have been prepared by reaction sequences involving treatment of josamycin with alcohols, phenol or 1-methyl-1Htetrazol-5-ylthiol in acidic media. Several tetrahydro derivatives of josamycin and isojosamycin have also been prepared by reaction sequences involving catalytic hydrogenation. From the ${ }^{1} \mathrm{H}$ NMR studies, it was found that the conformation of the macro-lactone portion of 13-O-methylisojosamycin dimethylacetal, a key intermediate, is flexible and changeable with variation of the solvent.
\end{abstract}

Josamycin ${ }^{1)}$ (leucomycin $\mathrm{A}_{3}{ }^{2)}$ ) is a macrolide antibiotic which has widely been used clinically and is produced by Streptomyces narbonensis var. josamyceticus. In attempts to improve the clinical characteristics, we have undertaken to prepare 9-O-alkyl derivatives of josamycin and 13-O-alkyl derivatives of isojosamycin. Josamycin is known to be converted, in aqueous acidic media, to isojosamycin (isoleucomycin $\mathrm{A}_{3}{ }^{3}$ ), which has a hydroxyl group at $\mathrm{C}-13$ produced by rearrangement ${ }^{4)}$ of the conjugated dienol system of josamycin. We found that the desired $O$-alkyl groups could be introduced into josamycin and isojosamycin by treatment of josamycin with alcohols in acidic media. The reactions of josamycin with phenol or 1-methyl- $1 H$-tetrazol-5-ylthiol are also described.

\section{Syntheses}

Treatment of josamycin in methanol containing $p$-toluenesulfonic acid $\left(0^{\circ} \mathrm{C}, 12\right.$ hours $)$ gave a mixture of 9-O-methyljosamycin dimethylacetal (1) and 13-O-methylisojosamycin dimethylacetal (2) in a ratio of $c a .1: 1$ in a moderate total yield $(66 \%)$. The above reaction conditions were the best among the conditions tested in terms of the yield, and superior to the yields of josamycin and isojosamycin obtained by the treatment of josamycin in an acidic aqueous medium. As by-products, methyl 4-Oisovaleryl- $\alpha$ - and $-\beta$-mycarosides ${ }^{5,8)}$ (3 and 4), josamycin dimethylacetal ${ }^{7)}$ (5), and several demycarosyl derivatives of josamycin and isojosamycin were obtained. Separation of $\mathbf{1}$ and $\mathbf{2}$ was difficult on account of their similar mobilities but was accomplished by repeated column chromatography to give pure $\mathbf{1}$ and $\mathbf{2}$ in low yields.

Similar treatment of josamycin with ethanol, propanol, or butanol gave mixtures of the corresponding 9-O-alkyljosamycin dialkylacetal [10(ethyl), 24(propyl), 33(butyl)] and 13-O-alkylisojosamycin dialkylacetal [11(ethyl), 25 (propyl), 34(butyl)] in $47 \%$ (for ethyl compound), $28 \%$ (propyl) and 14\% (butyl) yield, respectively. In each case, the formation of josamycin dialkylacetal [14(ethyl), 28(propyl), 
Chart 1

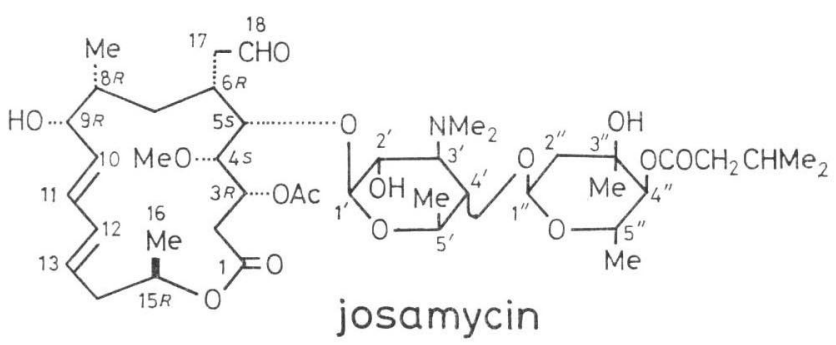

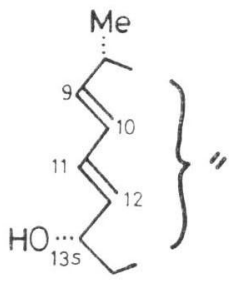

isojosamycin
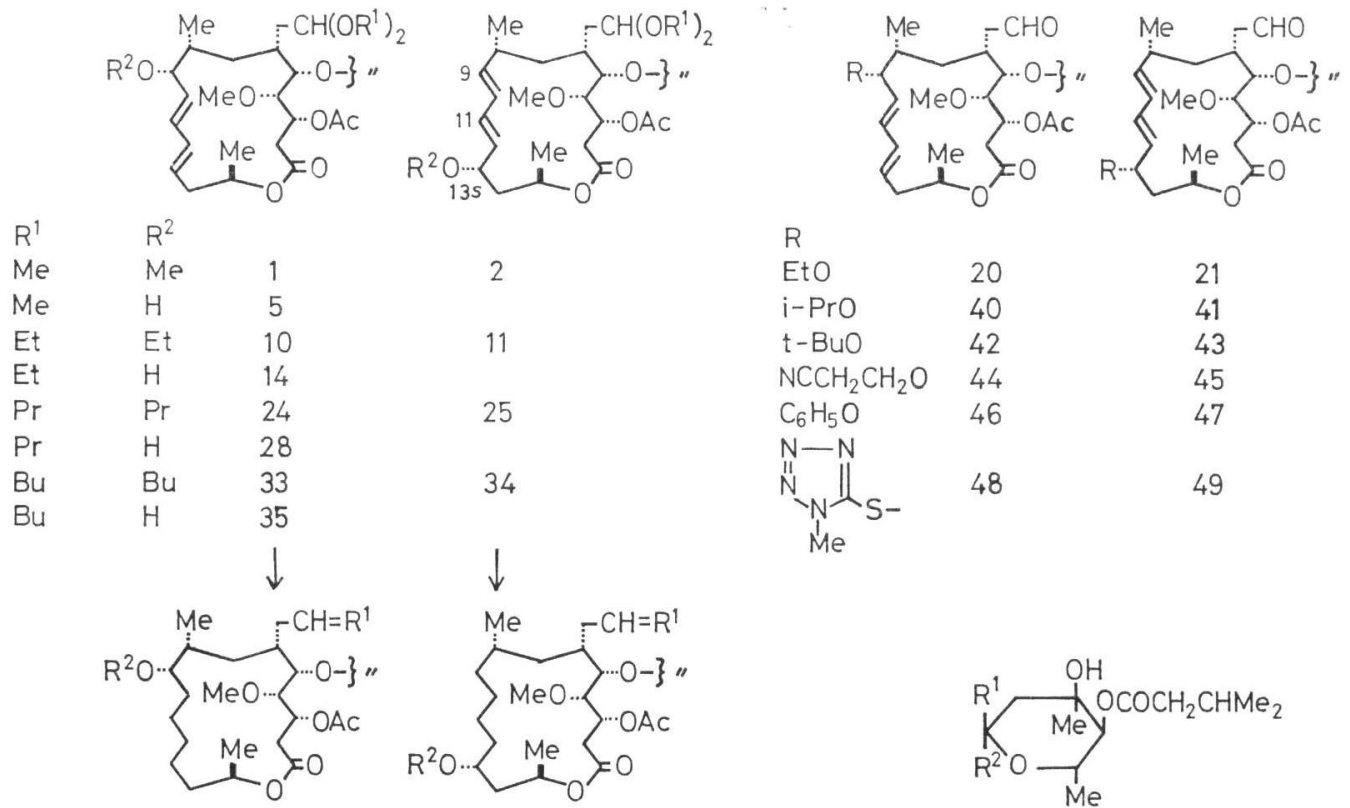

$\mathrm{R}$

$\begin{array}{lll}\text { EtO } & 20 & 21 \\ \mathrm{i}-\mathrm{PrO} & 40 & 41 \\ \mathrm{t}-\mathrm{BuO} & 42 & 43 \\ \mathrm{NCCH}_{2} \mathrm{CH}_{2} \mathrm{O} & 44 & 45 \\ \mathrm{C}_{6} \mathrm{H}_{5} \mathrm{O} & 46 & 47 \\ \mathrm{~N}-\mathrm{N} & \\ \mathrm{N} \mathrm{N}_{\mathrm{N}-}^{\mathrm{N}} & 48 & 49 \\ \mathrm{Me} & & \end{array}$

$R^{1} \quad R^{2}$

$(\mathrm{MeO})_{2} \quad \mathrm{Me} \quad 6$

$\begin{array}{llll}0 & \mathrm{Me} & 8 & 9\end{array}$

$\begin{array}{llll}(\text { EtO } & \text { Et } & 18 & 19\end{array}$

$\begin{array}{llll}\text { O } & \text { Et } & 22 & 23\end{array}$

$\begin{array}{lll}(\mathrm{PrO})_{2} & \mathrm{Pr} & 29\end{array}$

$\begin{array}{llll}0 & \mathrm{Pr} & 31 & 32\end{array}$

$\begin{array}{llll}(\mathrm{BuO})_{2} & \mathrm{Bu} & 36 & 37\end{array}$

$\begin{array}{llll}\mathrm{O} & \mathrm{Bu} & 38 & 39\end{array}$

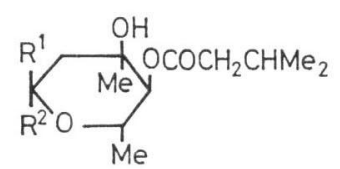

$R^{1} \quad R^{2}$

$\mathrm{MeO} H$

$\mathrm{H} \quad \mathrm{MeO} \quad 4$

EtO $\mathrm{H} \quad 12$

H Eto 13

PrO H 26

H $\quad$ PrO 27
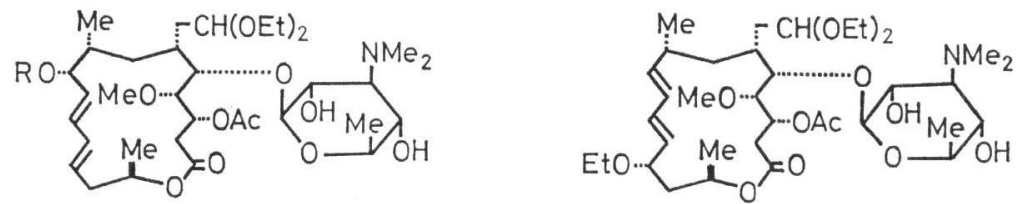

R

Et 15

H 17 
Table 1. Physicochemical properties of products.

\begin{tabular}{|c|c|c|c|c|c|c|c|}
\hline \multirow{2}{*}{$\begin{array}{l}\text { Compound } \\
\text { (ratio) }\end{array}$} & \multirow{2}{*}{ Nature* } & \multirow{2}{*}{$\begin{array}{c}{[\alpha]_{\mathrm{D}}^{15}} \\
\left(c 1, \mathrm{CHCl}_{3}\right)\end{array}$} & \multirow{2}{*}{$\mathrm{Rf}^{* * *}$} & \multirow{2}{*}{$\begin{array}{l}\text { Molecular } \\
\text { formula }\end{array}$} & \multicolumn{3}{|c|}{ Analysis: Found (Calcd.) } \\
\hline & & & & & $\mathrm{C}$ & $\mathrm{H}$ & $\mathrm{N}$ \\
\hline $1+2(1: 1)$ & a.p. & $-41^{\circ}$ & $0.42(0.56)$ & $\mathrm{C}_{45} \mathrm{H}_{77} \mathrm{NO}_{16}$ & $60.98(60.86)$ & $8.71(8.74)$ & $1.42(1.58)$ \\
\hline 1 & a.p. & $-40^{\circ}$ & 0.42 & $\mathrm{C}_{45} \mathrm{H}_{77} \mathrm{NO}_{16}$ & 60.99 & 8.61 & 1.52 \\
\hline 2 & a.p. & $-42^{\circ}$ & 0.42 & $\mathrm{C}_{45} \mathrm{H}_{77} \mathrm{NO}_{16}$ & 61.03 & 8.66 & 1.41 \\
\hline 5 & a.p. & $-44^{\circ}$ & $0.26(0.28)$ & $\mathrm{C}_{44} \mathrm{H}_{75} \mathrm{NO}_{16}$ & $60.21(60.46)$ & $8.48(8.65)$ & $1.67(1.60)$ \\
\hline 6 & $84 \sim 85^{\circ} \mathrm{C}$ & $-52^{\circ}$ & 0.42 & $\mathrm{C}_{45} \mathrm{H}_{81} \mathrm{NO}_{16}$ & $60.45(60.59)$ & $8.88(9.15)$ & $1.48(1.57)$ \\
\hline 7 & a.p. & $-60^{\circ}$ & 0.42 & $\mathrm{C}_{45} \mathrm{H}_{81} \mathrm{NO}_{16}$ & 60.33 & 8.88 & 1.56 \\
\hline 8 & a.p. & $-70^{\circ}$ & $0.40(0.35)$ & $\mathrm{C}_{43} \mathrm{H}_{75} \mathrm{NO}_{15}$ & $61.17(61.04)$ & $8.78(8.94)$ & $1.52(1.66)$ \\
\hline 9 & a.p. & $-68^{\circ}$ & $0.40(0.35)$ & $\mathrm{C}_{43} \mathrm{H}_{75} \mathrm{NO}_{15}$ & 60.96 & 8.83 & 1.63 \\
\hline $\mathbf{1 0}+\mathbf{1 1}(1: 1)$ & a.p. & $-60^{\circ}$ & 0.46 & $\mathrm{C}_{43} \mathrm{H}_{83} \mathrm{NO}_{18}$ & $62.28(61.98)$ & $9.03(8.99)$ & $1.49(1.51)$ \\
\hline 14 & a.p. & $-45^{\circ}$ & 0.29 & $\mathrm{C}_{40} \mathrm{H}_{70} \mathrm{NO}_{16}$ & $60.95(61.24)$ & $8.69(8.83)$ & $1.61(1.55)$ \\
\hline $18+19(1: 1)$ & a.p. & $-55^{\circ}$ & 0.46 & $\mathrm{C}_{48} \mathrm{H}_{87} \mathrm{NO}_{16}$ & $61.55(61.71)$ & $9.10(9.39)$ & $1.33(1.50)$ \\
\hline 20 & a.p. & $-59^{\circ}$ & 0.44 & $\mathrm{C}_{44} \mathrm{H}_{73} \mathrm{NO}_{15}$ & $61.89(61.73)$ & $8.65(8.60)$ & $1.50(1.64)$ \\
\hline 21 & a.p. & $-54^{\circ}$ & 0.40 & $\mathrm{C}_{44} \mathrm{H}_{73} \mathrm{NO}_{15}$ & 61.58 & 8.45 & 1.45 \\
\hline $22+23(1: 1)$ & a.p. & $-40^{\circ}$ & 0.42 & $\mathrm{C}_{44} \mathrm{H}_{77} \mathrm{NO}_{15}$ & $61.19(61.44)$ & $8.82(9.02)$ & $1.49(1.63)$ \\
\hline $24+25(1: 1)$ & a.p. & $-60^{\circ}$ & $0.49,0.51$ & $\mathrm{C}_{51} \mathrm{H}_{89} \mathrm{NO}_{16}$ & $62.96(63.00)$ & $8.92(9.22)$ & $1.32(1.44)$ \\
\hline 28 & a.p. & $-48^{\circ}$ & 0.32 & $\mathrm{C}_{48} \mathrm{H}_{83} \mathrm{NO}_{18}$ & $62.06(61.98)$ & $8.94(8.99)$ & $1.39(1.51)$ \\
\hline $29+30(1: 1)$ & a.p. & $-57^{\circ}$ & $0.49,0.51$ & $\mathrm{C}_{51} \mathrm{H}_{93} \mathrm{NO}_{16}$ & $61.71(62.74)$ & $9.34(9.60)$ & $1.40(1.43)$ \\
\hline $31+32(1: 1)$ & a.p. & $-63^{\circ}$ & 0.45 & $\mathrm{C}_{45} \mathrm{H}_{79} \mathrm{NO}_{15}$ & $62.07(61.83)$ & $9.09(9.11)$ & $1.38(1.60)$ \\
\hline $33+34(0.8: 1)$ & a.p. & $-59^{\circ}$ & $0.56,0.58$ & $\mathrm{C}_{54} \mathrm{H}_{95} \mathrm{NO}_{16}$ & $63.77(63.94)$ & $9.20(9.44)$ & $1.27(1.38)$ \\
\hline 35 & a.p. & $-47^{\circ}$ & 0.35 & $\mathrm{C}_{50} \mathrm{H}_{87} \mathrm{NO}_{16}$ & $62.40(62.67)$ & $8.96(9.15)$ & $1.52(1.46)$ \\
\hline $36+37(0.8: 1)$ & a.p. & $-51^{\circ}$ & $0.56,0.58$ & $\mathrm{C}_{54} \mathrm{H}_{99} \mathrm{NO}_{16}$ & $63.94(63.69)$ & $9.53(9.80)$ & $1.33(1.38)$ \\
\hline $38+39(0.8: 1)$ & a.p. & $-78^{\circ}$ & 0.47 & $\mathrm{C}_{46} \mathrm{H}_{81} \mathrm{NO}_{15}$ & $62.35(62.21)$ & $9.12(9.19)$ & $1.88(1.58)$ \\
\hline $40+41(3: 1)$ & a.p. & $-57^{\circ}$ & $0.35,0.38$ & $\mathrm{C}_{45} \mathrm{H}_{75} \mathrm{NO}_{15}$ & $62.37(62.12)$ & $8.72(8.69)$ & $1.53(1.61)$ \\
\hline $42+43(1.5: 1)$ & a.p. & $-63^{\circ}$ & $0.37,0.41$ & $\mathrm{C}_{46} \mathrm{H}_{77} \mathrm{NO}_{15}$ & $62.21(62.49)$ & $8.67(8.78)$ & $1.55(1.58)$ \\
\hline 42 & a.p. & $-60^{\circ}$ & 0.41 & $\mathrm{C}_{46} \mathrm{H}_{77} \mathrm{NO}_{15}$ & 61.89 & 8.52 & 1.68 \\
\hline $44+45(1: 1)$ & a.p. & $-56^{\circ}$ & $0.40,0.44$ & $\mathrm{C}_{45} \mathrm{H}_{72} \mathrm{~N}_{2} \mathrm{O}_{15}$ & $61.08(61.34)$ & $8.00(8.24)$ & $2.98(3.18)$ \\
\hline 44 & a.p. & $-61^{\circ}$ & 0.44 & $\mathrm{C}_{45} \mathrm{H}_{72} \mathrm{~N}_{2} \mathrm{O}_{15}$ & 61.11 & 8.20 & 3.00 \\
\hline 46 & a.p. & $-66^{\circ}$ & 0.47 & $\mathrm{C}_{47} \mathrm{H}_{73} \mathrm{NO}_{15}$ & $63.21(63.28)$ & $8.01(8.25)$ & $1.38(1.57)$ \\
\hline 47 & a.p. & $-64^{\circ}$ & 0.32 & $\mathrm{C}_{47} \mathrm{H}_{73} \mathrm{NO}_{15}$ & 63.40 & 8.10 & 1.48 \\
\hline 48 & $152 \sim 155^{\circ} \mathrm{C}$ & $-57^{\circ}$ & 0.39 & $\mathrm{C}_{44} \mathrm{H}_{71} \mathrm{~N}_{5} \mathrm{O}_{14} \mathrm{~S}$ & $57.34(57.06)$ & $7.84(7.73)$ & $7.68(7.56)$ \\
\hline & & & & & & S $3.61(3.46)$ & \\
\hline 49 & a.p. & $-32^{\circ}$ & 0.35 & $\mathrm{C}_{44} \mathrm{H}_{71} \mathrm{~N}_{5} \mathrm{O}_{14} \mathrm{~S}$ & 56.80 & 7.45 & 7.50 \\
\hline & & & & & & S 3.26 & \\
\hline
\end{tabular}

* Melting points or amorphous powder (a.p.)

** The value obtained on TLC with benzene - acetone (3:1). The values in parentheses are for benzene - methanol (10: 1$)$. 
Table 2. Minimal inhibitory

\begin{tabular}{|c|c|c|c|c|c|c|c|c|}
\hline \multirow[b]{2}{*}{ Test organism } & $\mathrm{JM}^{*}$ & $4 \mathrm{HJM}^{*}$ & 8 & 9 & 20 & 21 & $22+23$ & $31+32$ \\
\hline & & & $4 \mathrm{H} 9 \mathrm{Me}^{*}$ & $4 \mathrm{H} 13 \mathrm{Me}^{*}$ & $9 \mathrm{Et}$ & $13 \mathrm{Et}$ & $\begin{array}{l}\text { 4H9Et } \\
4 \mathrm{H} 13 \mathrm{Et}\end{array}$ & $\begin{array}{l}\text { 4H9Pr } \\
4 \mathrm{H} 13 \mathrm{Pr}\end{array}$ \\
\hline Staph. aureus 193 & 12.5 & 12.5 & 12.5 & 25 & 12.5 & 25 & 12.5 & 25 \\
\hline$" \quad " \quad \mathrm{EMf}^{* *}$ & 3.12 & 3.12 & 3.12 & 3.12 & 6.25 & 6.25 & 6.25 & 6.25 \\
\hline$" \quad$ FDA 209P & 0.78 & 1.56 & 1.56 & 1.56 & 3.12 & 6.25 & 0.78 & 3.12 \\
\hline "Smith & 0.78 & 0.78 & 0.78 & 1.56 & 1.56 & 3.12 & 0.78 & 3.12 \\
\hline " MS 8800 & $>100$ & $>100$ & $>100$ & $>100$ & $>100$ & $>100$ & $>100$ & $>100$ \\
\hline $\begin{array}{l}\text { Micrococcus flavus } \\
\text { FDA } 16\end{array}$ & $<0.2$ & $<0.2$ & 0.39 & 0.39 & 0.78 & 0.78 & $<0.2$ & 1.56 \\
\hline $\begin{array}{l}\text { Sarcina lutea } \\
\text { PCI } 1001\end{array}$ & $<0.2$ & $<0.2$ & 0.39 & $<0.2$ & 0.39 & 0.39 & $<0.2$ & 0.78 \\
\hline $\begin{array}{l}\text { B. subtilis NRRL } \\
\text { B-558 }\end{array}$ & 0.78 & 0.78 & 1.56 & 1.56 & 1.56 & 3.12 & 1.56 & 3.12 \\
\hline $\begin{array}{c}\text { Corynebact. bovis } \\
1810\end{array}$ & 0.2 & 0.78 & 0.78 & 0.78 & 0.78 & 1.56 & 0.2 & 1.56 \\
\hline E. coli $\mathrm{NIHJ}$ & $>100$ & $>100$ & $>100$ & $>100$ & $>100$ & $>100$ & $>100$ & $>100$ \\
\hline " K-12 & $>100$ & $>100$ & $>100$ & $>100$ & $>100$ & $>100$ & $>100$ & $>100$ \\
\hline $\begin{array}{c}\text { K. pneumoniae } \\
\text { PCI } 602\end{array}$ & 50 & 100 & 100 & 50 & $>100$ & $>100$ & $>100$ & $>100$ \\
\hline $\begin{array}{c}\text { Sh. dysenteriae } \\
\text { JS } 11910\end{array}$ & 6.25 & 12.5 & 25 & 25 & 50 & 100 & 100 & 100 \\
\hline Sal. enteritidis 1891 & 12.5 & 25 & 50 & 50 & 50 & 100 & 100 & 100 \\
\hline$P$. aeruginosa A3 & $>100$ & $>100$ & $>100$ & $>100$ & $>100$ & $>100$ & $>100$ & $>100$ \\
\hline
\end{tabular}

* Abbreviations: JM, josamycin; $4 \mathrm{HJM}$, tetrahydrojosamycin ${ }^{8)} ; 4 \mathrm{H}$ is for the tetrahydro compounds;

** Erythromycin-resistant strain.

35(butyl)] was observed in the early stage of reaction, followed by the formation of the desired 9-Oand 13-O-alkyl derivatives together with some alcoholyzed products formed by cleavage of the mycarosyl bonding. These were alkyl 4-O-isovaleryl- $\alpha$ - and $-\beta$-mycarosides (12 and $\mathbf{1 3}$ for ethyl, $\mathbf{2 6}$ and 27 for propyl), de(mycarosyl)josamycin dialkylacetal (17 for ethyl), 9-O-alkyl-de(mycarosyl)josamycin dialkylacetal (15 for ethyl), and 13-O-alkyl-de(mycarosyl)isojosamycin dialkylacetal (16 for ethyl).

Treatment of josamycin with isopropanol, tert-butanol, 2-cyanoethanol or phenol in a similar manner gave no dialkyl- or diphenylacetal derivative, giving only monosubstituted derivatives, namely, 9-O-isopropyl- (40), 9-O-(tert-butyl)- (42), 9-O-(2-cyanoethyl)- (44), and 9-O-phenyljosamycin (46), together with the corresponding 13-O-alkylisomers, that is 13-O-isopropyl- (41), 13-O-(tert-butyl)(43), 13-O-(2-cyanoethyl)- (45), and 13-O-phenylisojosamycin (47), in yields of $8 \%$ (for the mixture of 40 and $\mathbf{4 1}$ ), $9.9 \%$ (for the mixture of $\mathbf{4 2}$ and $\mathbf{4 3}$ ), $52 \%$ (for the mixture of $\mathbf{4 4}$ and $\mathbf{4 5}$ ), $9 \%$ (46) and $42 \%$ (47). No formation of the expected diacetal derivative, and low yields of the desired $O$-alkyl derivatives except for the cyanoethyl derivatives may be ascribed to the bulkiness of the alkyl groups introduced. In the case of cyanoethylation, formation of the corresponding dialkyl-acetals may be expected, but none of them were isolated.

Isolation of 9-O-ethyljosamycin (20) and 13-O-ethylisojosamycin (21) from the reaction mixture obtained by the procedure described was difficult on account of the low yield of the desired derivatives. However, when josamycin was treated in acetonitrile in the presence of trifluoroacetic acid for rather long reaction period of time (1 month), 20 and $\mathbf{2 1}$ were formed in detectable amounts, and they were separated, after laborious column chromatography, in low yields. 
concentration $(\mathrm{mcg} / \mathrm{ml})$.

\begin{tabular}{|c|c|c|c|c|c|c|c|c|c|}
\hline $38+39$ & $40+41$ & 42 & $42+43$ & 44 & $44+45$ & 46 & 47 & 48 & 49 \\
\hline $\begin{array}{c}4 \mathrm{H} 9 \mathrm{Bu} \\
4 \mathrm{H} 13 \mathrm{Bu}\end{array}$ & $\begin{array}{l}9 i \mathrm{Pr} \\
13 i \mathrm{Pr}\end{array}$ & $9 t \mathrm{Bu}$ & $\begin{array}{c}9 t \mathrm{Bu} \\
13 t \mathrm{Bu}\end{array}$ & & & $9 \mathrm{Ph}$ & $13 \mathrm{Ph}$ & & \\
\hline 12.5 & 12.5 & 12.5 & 25 & 12.5 & 12.5 & 25 & 12.5 & 6.25 & 6.25 \\
\hline 6.25 & 3.12 & 6.25 & 6.25 & 6.25 & 6.25 & 12.5 & 12.5 & 1.56 & 1.56 \\
\hline 6.25 & 3.12 & 1.56 & 3.12 & 0.78 & 1.56 & 6.25 & 3.12 & 0.78 & 0.78 \\
\hline 3.12 & 1.56 & 3.12 & 3.12 & 0.78 & 1.56 & 3.12 & 0.78 & 0.39 & 0.39 \\
\hline$>100$ & $>100$ & $>100$ & $>100$ & $>100$ & $>100$ & $>100$ & $>100$ & $>100$ & $>100$ \\
\hline 1.56 & 0.78 & 1.56 & 1.56 & 0.2 & 0.78 & 0.39 & $<0.2$ & $<0.2$ & 0.39 \\
\hline$<0.2$ & 0.78 & 0.39 & 0.78 & 0.39 & 0.39 & 0.39 & 0.39 & $<0.2$ & 0.2 \\
\hline 6.25 & 3.12 & 3.12 & 3.12 & 0.78 & 1.56 & 3.12 & 0.78 & 0.39 & 0.39 \\
\hline 1.56 & 0.78 & 0.39 & 0.78 & 0.39 & 0.78 & 0.78 & 0.39 & 0.2 & 0.2 \\
\hline$>100$ & $>100$ & $>100$ & $>100$ & $>100$ & $>100$ & $>100$ & $>100$ & $>100$ & $>100$ \\
\hline$>100$ & $>100$ & $>100$ & $>100$ & $>100$ & $>100$ & $>100$ & $>100$ & $>100$ & $>100$ \\
\hline$>100$ & $>100$ & $>100$ & $>100$ & $>100$ & 100 & $>100$ & $>100$ & 50 & 25 \\
\hline$>100$ & $>100$ & $>100$ & $>100$ & 50 & 50 & $>100$ & $>100$ & 12.5 & 12.5 \\
\hline$>100$ & $>100$ & $>100$ & $>100$ & 50 & 50 & $>100$ & $>100$ & 6.25 & 6.25 \\
\hline$>100$ & $>100$ & $>100$ & $>100$ & $>100$ & $>100$ & $>100$ & $>100$ & $>100$ & $>100$ \\
\hline
\end{tabular}

9 Alkyl and 13 Alkyl is for the 9-O-alkylated and 13-O-alkylated compounds, respectively.

Since acetalation of the aldehyde group at $\mathrm{C}-18$ gave rise to compounds having no antibacterial activity, the acetal derivatives described above were deacetalated after catalytic hydrogenation of the double bonds, the alkoxyl groups at C-9 or C-13 being fixed in that positions by the latter reaction. The tetrahydro acetals [6 and 7 (Me derivatives), 18 and 19(Et), 29 and 30(Pr), 36 and 37(Bu)] were deacetalated to give 9-O-alkyl-10,11,12,13-tetrahydrojosamycin [8(Me), 22(Et), 31( $\mathrm{Pr}), 38(\mathrm{Bu})]$ and 13-O-alkyl-9,10,11,12-tetrahydroisojosamycin [9(Me), 23(Et), 32( $\mathrm{Pr}), 39(\mathrm{Bu})]$.

In another experiment, josamycin was treated with 1-methyl-1H-tetrazol-5-ylthiol, which has often been used in the preparation of $\beta$-lactam antibiotics ${ }^{8)}$, to give 9-(1-methyl-1H-tetrazol-5-ylthio)josamycin (48) and 13-(1-methyl-1H-tetrazol-5-ylthio)isojosamycin (49) in moderate yields, respectively, without formation of thioacetals.

Physicochemical properties of the above mentioned prepared are shown in Table 1, and the antibacterial spectra of 9-O-alkyljosamycins, 9-O-alkyl-tetrahydrojosamycins, 13-O-alkylisojosamycins, 13-O-alkyltetrahydroisojosamycins, $\mathbf{4 8}$ and $\mathbf{4 9}$ are shown in Table 2 with those of josamycin and tetrahydrojosamycin ${ }^{9,10)}$. No substantial difference was observed in the antibacterial spectra.

\section{Structural Studies}

The structure of 1 was determined by comparison of the ${ }^{1} \mathrm{H}$ NMR spectra of $\mathbb{1}$ and josamycin dimethylacetal ${ }^{7)}(5)$ measured in chloroform- $d\left(\mathrm{CDCl}_{3}\right)$ at $250 \mathrm{MHz}$. Major differences between the spectra were the appearance of the C(9)OMe group ( $\delta 3.58)$ in $\mathbf{1}$, and the change in the shift values of 
Fig. 1.
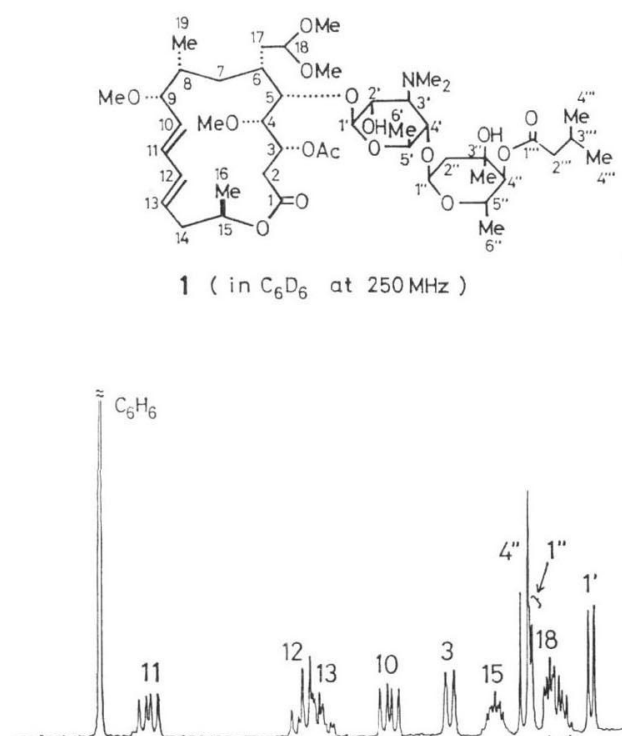

$4 " \mid$
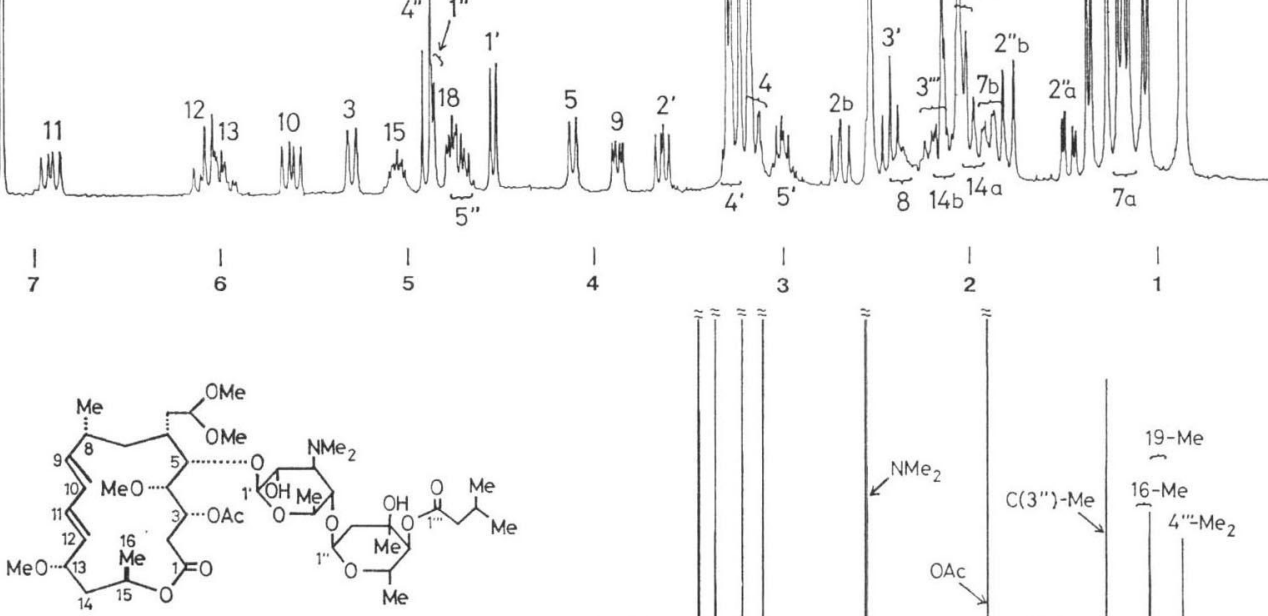

$2\left(\right.$ in $\left.\mathrm{C}_{6} \mathrm{D}_{6}\right)$
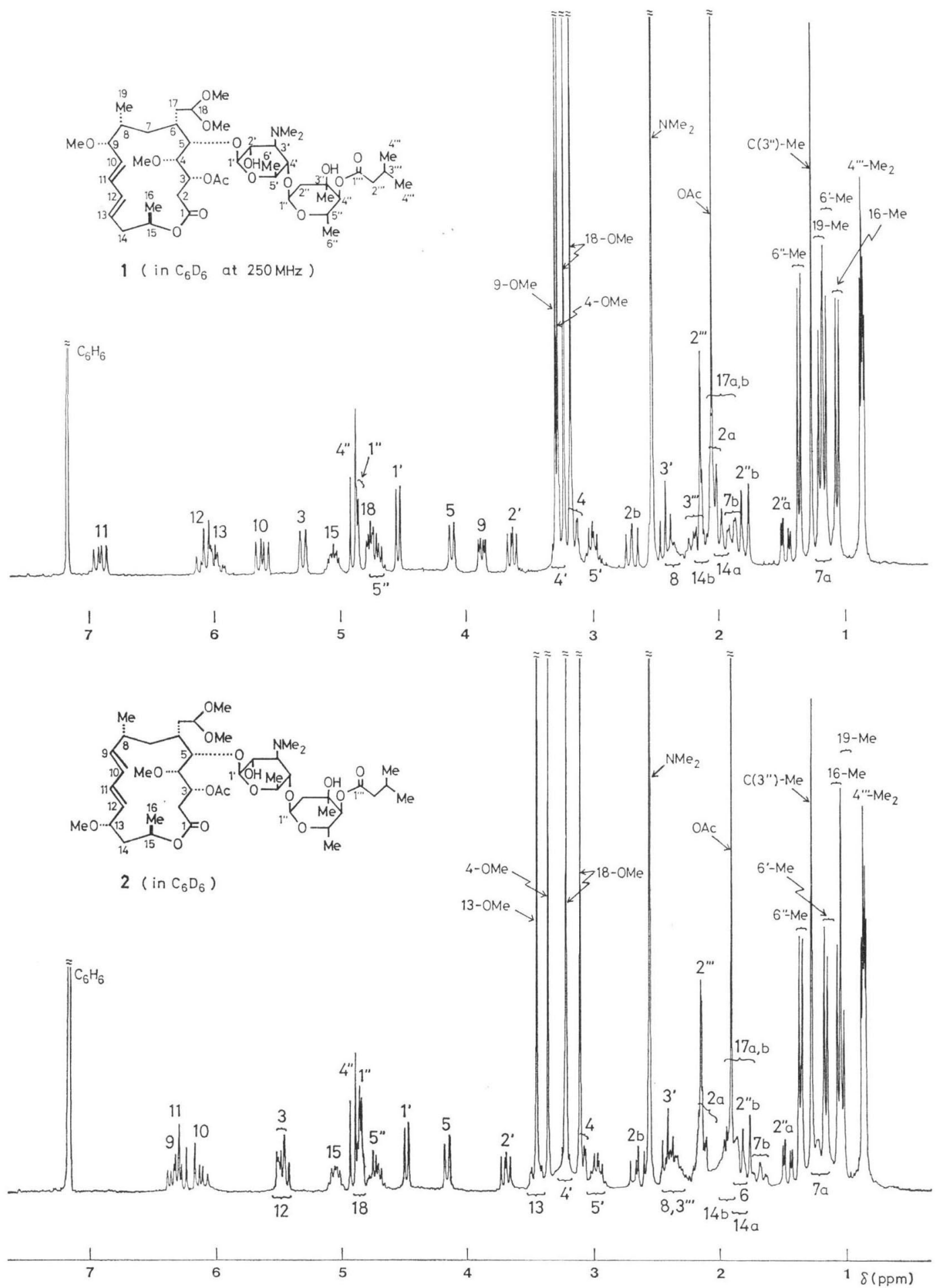
H-9 (5: $\delta 4.20,1: \delta 3.58)$; other signals appeared at similar shifts with similar patterns in both compounds with respect to the corresponding protons. The spectrum of $\mathbf{1}$ in benzene- $d_{6}\left(\mathrm{C}_{6} \mathrm{D}_{6}\right)$ is shown in Fig. 1. All shift-values and coupling constants of $\mathbf{1}$ (Table 3) were certified by decoupling. No noticeable differences in $J$ values of the corresponding protons were observed in $\mathrm{CDCl}_{3}$ and $\mathrm{C}_{6} \mathrm{D}_{6}$, indicating that the conformations of $\mathbf{1}$ in both solvents are substantially the same. The shift-values of the corresponding protons were, however, quite different, for some protons.

The structure of 2 was next studied. Double irradiation starting from $\mathrm{H}-15$ (the proton was clearly distinct from other protons by the indication of its $\delta$-value and the splitting pattern) to $\mathrm{H}-8$ through $\mathrm{H}-13$ revealed the sequence of $\mathrm{HC}(15) \mathrm{Me}-\mathrm{C}(14) \mathrm{HH}-\mathrm{HC}(13) \mathrm{OMe}-\mathrm{HC}(12)=\mathrm{C}(11) \mathrm{H}-\mathrm{HC}(10)=\mathrm{C}(9) \mathrm{H}-$ $\mathrm{HC}(8) \mathrm{Me}-\mathrm{C}$ (see Experimental and Table 3). This result indicates that the first double bond (at C-12) appears at the 3rd carbon from $\mathrm{C}-15$ and, therefore, 2 has the same structure with that of isojosamycin with respect to the macro-lactone ring. Therefore, the absolute configuration at C-13 should be $S$.

In order to clarify the conformation of the macro-lactone ring of $2, J$ values of 2 in $\mathrm{CDCl}_{3}$ or $\mathrm{C}_{6} \mathrm{D}_{6}$ were measured. The results are shown in Table 3 and Fig. 1 . It is worthwhile to compare the above results with those obtained by X-ray crystallography of de(mycarosyl)isojosamycin reported by HIRAMATSU et al. ${ }^{11,12)}$, because the structures of the macro-lactone rings of both the compounds are considered to be substantially the same. The dihedral angles (cited in the 13th column of Table 3) relating to vicinal hydrogens $\left(\mathrm{H}_{2}-\mathrm{C}_{\mathrm{B}}-\mathrm{C}_{\mathbf{A}}-\mathrm{H}_{1}\right)$ of de(mycarosyl)isojosamycin are calculated from the reported $^{11,12)}$ dihedral angles created by $\mathrm{C}_{1}-\mathrm{C}_{\mathbf{A}}$ and $\mathrm{C}_{2}-\mathrm{C}_{\mathbf{B}}$ in $\mathrm{C}_{2}-\stackrel{\mathrm{I}}{\mathrm{C}}_{\mathbf{B}}-\stackrel{\mathrm{C}}{\mathrm{C}}_{\mathbf{A}}-\mathrm{C}_{1}$ system of the compound, with an assumption that the hydrogens attached at each carbon are bonded without deviation from the ideal positions of tetrahedral geometry. The ${ }^{3} J_{\mathrm{H}, \mathrm{H}}$ values shown in the last column of the Table are claculated from the modified Karplus equation based on the calculated angles (on the 13th column). For the ${ }^{3} J_{\mathrm{H}, \mathrm{H}}$ of the C-C chain between $\mathrm{C}(6)-\mathrm{C}(8)$, the equation of $\operatorname{ABRAHAM}^{13,14)}\left(J=12.4 \cdot \cos ^{2} \phi\right.$ for $0 \leqq \phi \leqq 90^{\circ}$, and $J=14.3 \cdot \cos ^{2} \phi$ for $90^{\circ} \leqq \phi \leqq 180^{\circ}$ ) is adopted, and for the other ${ }^{3} J_{\mathrm{H}, \mathrm{H}}$ of the saturated bondings, the equation $\left(J=14.4 \cdot \cos ^{2} \phi\right.$ for $0 \leqq \phi \leqq 90^{\circ}$, and $J=11 \cdot \cos ^{2} \phi$ for $\left.90^{\circ} \leqq \phi \leqq 180^{\circ}\right)$ is adopted, the latter equation being made from the original Karplus equation ${ }^{15,16)}$ by adding the assumption that ${ }^{3} J_{\mathrm{H}, \mathrm{H}}$ is $3.6 \mathrm{~Hz}$ for dihedral angle of $60^{\circ}, 0 \mathrm{~Hz}$ for $90^{\circ}$, and $11 \mathrm{~Hz}$ for $180^{\circ}$, the $J$ values being accepted ${ }^{17)}$ in sugar chemistry. Comparison of the calculated $J$ values (on the last column) with those of 2 obtained in $\mathrm{C}_{6} \mathrm{D}_{6}$ (on the 11th column) showed reasonable agreement with respect to the corresponding values. The $J$ values of 2 measured in $\mathrm{CDCl}_{3}$ (on the 10th column), however, showed discrepancy with the values relating to H-14 (Table 3). The results indicate that the conformation of the macrolactone ring of the crystalline de(mycarosyl)isojosamycin and that of compound 2 dissolved in $\mathrm{C}_{6} \mathrm{D}_{6}$ resemble each other, and that the conformation in the range of $C(13)-C(15)$ is suggested to be flexible and changeable depending on the solvent used.

On the flexibility in the range of $\mathrm{C}-13$ to $\mathrm{C}-15$, we want to add another observation obtained by changing the solvent ratio of $\mathrm{CDCl}_{3}$ and $\mathrm{C}_{6} \mathrm{D}_{6}$. In neat $\mathrm{CDCl}_{3}, \mathrm{H}-15$ appeared at $\delta 4.99$ as a comparatively sharp multiplet (sextet?), the assignment being made by the irradiation at $\delta 1.22$ [C(15)-Me], whereupon H-15 became double doublets [apparant triplet; $J \simeq 6$ and $\simeq 7 \mathrm{~Hz}\left(=J_{14 \mathrm{a}, 15} \text { and } J_{14 \mathrm{~b}, 15}\right)^{*}$ ] by the disappearance of the couplings with the $\mathrm{C}(15)$-methyl protons. In $\mathrm{C}_{6} \mathrm{D}_{6}$, however, $\mathrm{H}-15$ ap-

* It seems that, in $\mathrm{CDCl}_{3}$, dihedral angles formed between $\mathrm{C}_{12}-\mathrm{C}_{13}$ and $\mathrm{C}_{14}-\mathrm{C}_{15}\left(+78^{\circ}\right)$, and $\mathrm{C}_{13} \mathrm{C}_{14}$ and $\mathrm{C}_{15} \mathrm{O}\left(-84^{\circ}\right)$ reported $^{11,12)}$ in the crystalline state, change to $\sim+40^{\circ}$ and $\sim-50^{\circ}$, respectively. 
Table 3. ${ }^{1} \mathrm{H}$ NMR data of $\mathbf{1}$ and $\mathbf{2}$.

\begin{tabular}{|c|c|c|c|c|c|c|c|c|c|c|c|c|c|}
\hline & \multicolumn{5}{|c|}{1} & \multicolumn{5}{|c|}{2} & \multirow[b]{2}{*}{$\mathrm{H}, \mathrm{H}^{* 1}$} & \multirow[b]{2}{*}{ angle $\left({ }^{\circ}\right)^{* 1}$} & \multirow[b]{2}{*}{$J(\mathrm{~Hz})^{* 2}$} \\
\hline & in $\underset{(\delta)}{\mathrm{CDCl}_{3}}$ & in $\begin{array}{c}\mathrm{C}_{6} \mathrm{D}_{0} \\
(\delta)\end{array}$ & $J_{\mathrm{H}, \mathrm{H}}$ & in $\underset{J(\mathrm{~Hz})}{\mathrm{CDCl}_{3}}$ & $\begin{array}{c}{ }_{3} \text { in } \mathrm{C}_{6} \mathrm{D}_{6} \\
J(\mathrm{~Hz})\end{array}$ & in $\underset{(\delta)}{\mathrm{CDCl}_{3}}$ & in $\underset{(\delta)}{\mathrm{C}_{6} \mathrm{D}_{B}}$ & $J_{\mathrm{H}, \mathrm{H}}$ & in $\mathrm{CDCl}_{3}$ & $\begin{array}{c}\text { in } \mathrm{C}_{6} \mathrm{D}_{B} \\
J(\mathrm{~Hz})\end{array}$ & & & \\
\hline \multirow[t]{2}{*}{$\mathrm{H}-2 \mathrm{a}$} & $2.26 \mathrm{~d}$ & $2.03 \mathrm{~d}$ & $2 a, 2 b$ & 13.5 & 13 & \multirow[t]{2}{*}{$2.21 \mathrm{~d}$} & \multirow[t]{2}{*}{$2.14 \mathrm{dd}$} & $2 a, 2 b$ & 15 & 15.5 & & & \\
\hline & & & $2 \mathrm{a}, 3$ & $\simeq 1$ & $\simeq 1$ & & & $2 a, 3$ & $\simeq 0$ & $\simeq 1.5$ & $2 \mathrm{a}, 3$ & 57 & 4.3 \\
\hline$-2 b$ & $2.73 \mathrm{dd}$ & $2.69 \mathrm{dd}$ & $2 b, 3$ & 11 & 11 & $2.72 \mathrm{dd}$ & $2.65 \mathrm{dd}$ & $2 b, 3$ & 11 & 12 & $2 b, 3$ & 177 & 11 \\
\hline-3 & 5.08 & $5.29 \mathrm{~d}(\mathrm{br})$ & 3,4 & & $\simeq 1.5$ & $5.22 \mathrm{~d}(\mathrm{br})$ & $5.47 \mathrm{~d}(\mathrm{br})$ & 3,4 & $\simeq 1.5$ & $\simeq 2.5$ & 3,4 & 50 & 5.9 \\
\hline-4 & 3.25 & $3.14 \mathrm{dd}$ & & & & $\sim 3.2$ & $3.08 \mathrm{dd}(?)$ & & & & & & \\
\hline \multirow{2}{*}{-5} & $3.89 \mathrm{~d}$ & $4.11 \mathrm{~d}$ & 4,5 & 9.5 & 9 & \multirow[t]{2}{*}{$3.87 \mathrm{~d}$} & \multirow[t]{2}{*}{$4.15 \mathrm{~d}$} & 4,5 & 9.5 & 9.5 & 4,5 & 175 & 10.9 \\
\hline & & & 5,6 & $\simeq 0.5$ & $\simeq 0.5$ & & & 5,6 & $\simeq 0.5$ & $\simeq 0.5$ & 5,6 & 61 & 3.4 \\
\hline-6 & $\sim 1.63$ & & & & & $\sim 1.7$ & $\sim 1.9$ & & & & & & \\
\hline$-7 \mathrm{a}$ & \multicolumn{2}{|c|}{0.90 br $\mathrm{t} ? \sim 1.2$} & & & & 1.19 & $1.22 ?$ & & & & & & \\
\hline \multirow[t]{5}{*}{$-7 b$} & $1.47 \mathrm{dt}$ & $\sim 1.87 \mathrm{dt} ?$ & $7 \mathrm{a}, 7 \mathrm{~b}=$ & $\simeq 12.5$ & $\simeq 12.5$ & $1.42 \mathrm{dt}$ & $1.68 \mathrm{dt}$ & $7 \mathrm{a}, 7 \mathrm{~b}$ & $\simeq 12.5$ & & & & \\
\hline & & & $6,7 \mathrm{a}=$ & $\simeq 12.5$ & & & & $6,7 \mathrm{a}$ & $\simeq 12.5$ & $\simeq 12.5$ & $6,7 \mathrm{a}$ & 156 & 11.9 \\
\hline & & & $6,7 b$ & & & & & $6,7 b$ & & & $6,7 b$ & 84 & 0.2 \\
\hline & & & $7 a, 8$ & $\simeq 2$ & & & & $7 a, 8$ & & & $7 a, 8$ & 179 & 14.3 \\
\hline & & & $7 b, 8$ & 3 & & & & $7 b, 8$ & 2.5 & 3.3 & $7 \mathrm{~b}, 8$ & 61 & 3.4 \\
\hline-8 & $\sim 2.15$ & $\sim 2.35$ & & & & $\sim 2.3$ & 2.35 & & & & & & \\
\hline \multirow[t]{2}{*}{-9} & $3.58 \mathrm{dd}$ & $3.87 \mathrm{dd}$ & 8,9 & & 4 & \multirow[t]{2}{*}{$6.23 \mathrm{dd}$} & \multirow[t]{2}{*}{$6.33 \mathrm{dd}$} & 8,9 & 6.5 & 6.8 & & & \\
\hline & & & 9,10 & 9.5 & 9.5 & & & 9,10 & 15.5 & 15.5 & & & \\
\hline-10 & $5.47 \mathrm{dd}$ & $5.62 \mathrm{dd}$ & 10,11 & 15 & 15 & $6.10 \mathrm{dd}$ & $6.12 \mathrm{dd}$ & 10,11 & 9.5 & 9.5 & & & \\
\hline-11 & $6.54 \mathrm{dd}$ & $6.91 \mathrm{dd}$ & 11,12 & 10.5 & 9.5 & $6.22 \mathrm{dd}$ & $6.27 \mathrm{dd}$ & 11,12 & 15 & 15 & & & \\
\hline-12 & $6.09 \mathrm{dd}$ & $6.08 \mathrm{dd}$ & 12,13 & 15 & 15 & $5.37 \mathrm{dd}$ & $5.46 \mathrm{dd}$ & 12,13 & 9 & 9.5 & & & \\
\hline-13 & 5.74 ddd & $6.00 \mathrm{ddd}$ & & & & $\sim 3.6$ & 3.44 (dt?) & & & & & & \\
\hline$-14 a$ & $\sim 2.09$ & 1.98 & $13,14 \mathrm{a}$ & 10.5 & $\int^{7.5}$ & \multirow{4}{*}{$1.89 \mathrm{t}$} & 1.86 & $13,14 \mathrm{a}$ & $\simeq 7$ & 3.3 & $13,14 a$ & 78 & 0.6 \\
\hline \multirow[t]{3}{*}{$-14 b$} & $\sim 2.16$ & $\sim 2.1$ & $13,14 b$ & 3.8 & 14 & & \multirow[t]{3}{*}{$\sim 2$} & $13,14 b$ & $\simeq 7$ & $\simeq 9.5$ & $13,14 b$ & 162 & 9.9 \\
\hline & & & $14 \mathrm{a}, 15$ & 3 & 4 & & & $14 \mathrm{a}, 15$ & $\int \simeq 6$ & $\simeq 0$ & $14 \mathrm{a}, 15$ & 84 & 0.2 \\
\hline & & & $14 b, 15$ & 10 & 10.5 & & & $14 b, 15$ & $\simeq 7$ & 9.5 & $14 b, 15$ & 156 & 9.2 \\
\hline \multirow{2}{*}{$\begin{array}{l}-15 \\
-17 a,-17 b\end{array}$} & $5.03 \mathrm{~m}$ & $5.05 \mathrm{~m}$ & & & & \multicolumn{2}{|c|}{$4.99 \mathrm{~m}$ (sextet) $\quad 5.04 \mathrm{~m}$} & & & & & & \\
\hline & & $\simeq 2.0 \sim 2.2$ & $\begin{array}{l}17 \mathrm{a}, 18 \\
17 \mathrm{~b}, 18\end{array}$ & & $\left\{\begin{array}{l}3.8 \\
7.5\end{array}\right.$ & $1.55 \sim 1.85$ & $1.83 \sim 2.0$ & & & & & & \\
\hline-18 & $\sim 4.5$ & $4.78 \mathrm{dd}$ & & & & $\sim 4.5$ & $\sim 4.85$ & & & & & & \\
\hline
\end{tabular}


Table 3. (Continued)

\begin{tabular}{|c|c|c|c|c|c|c|c|c|c|c|c|c|c|}
\hline & \multicolumn{5}{|c|}{1} & \multicolumn{5}{|c|}{2} & \multirow[b]{2}{*}{$\mathrm{H}, \mathrm{H}^{* 1}$} & \multirow[b]{2}{*}{ angle $\left({ }^{\circ}\right)^{* 1}$} & \multirow[b]{2}{*}{$J(\mathrm{~Hz})^{* 2}$} \\
\hline & in $\underset{(\delta)}{\mathrm{CDCl}_{3}}$ & in $\underset{(\delta)}{\mathrm{C}_{6} \mathrm{D}_{\theta}}$ & $J_{\mathrm{H}, \mathrm{H}}$ in & $\underset{J(\mathrm{~Hz})}{\mathrm{n}^{\mathrm{CDCl}}}$ & $\begin{array}{c}\text { in } \mathrm{C}_{\theta} \mathrm{D}_{6} \\
J(\mathrm{~Hz})\end{array}$ & in $\underset{(\delta)}{\mathrm{CDCl}_{3}}$ & in $\underset{(\delta)}{\mathrm{C}_{6} \mathrm{D}_{\theta}}$ & $J_{\mathrm{H}, \mathrm{H}}$ & $\begin{array}{c}\text { in } \mathrm{CDCl}_{3} \\
J(\mathrm{~Hz})\end{array}$ & $\begin{array}{c}\text { in } \mathrm{C}_{6} \mathrm{D}_{\beta} \\
J(\mathrm{~Hz})\end{array}$ & & & \\
\hline 3-O-Ac & $2.12 \mathrm{~s}$ & $2.05 \mathrm{~s}$ & & & & $2.10 \mathrm{~s}$ & $1.91 \mathrm{~s}$ & & & & & & \\
\hline 4-OMe & $3.28 \mathrm{~s}$ & $(3.27 \mathrm{~s})$ & & & & $3.31 \mathrm{~s}$ & $3.36 \mathrm{~s}$ & & & & & & \\
\hline $\mathrm{C}(8)-\mathrm{Me}$ & $0.98 \mathrm{~d}$ & $1.19 \mathrm{~d}$ & & 7 & 7 & $1.08 \mathrm{~d}$ & $1.04 \mathrm{~d}$ & & 7 & 7 & & & \\
\hline 9-OMe & $3.55 \mathrm{~s}$ & $(3.29 \mathrm{~s})^{* 3}$ & & & & & & & & & & & \\
\hline 13-OMe & & & & & & 3.58 & $3.44 \mathrm{~s}$ & & & & & & \\
\hline $\mathrm{C}(15)-\mathrm{Me}$ & $1.26 \mathrm{~d}$ & $1.05 \mathrm{~d}$ & & 7 & 7 & $1.22 \mathrm{~d}$ & $1.06 \mathrm{~d}$ & & & 6 & & & \\
\hline \multirow[t]{2}{*}{$\mathrm{C}(18)(\mathrm{OMe})_{2}$} & $3.20 \mathrm{~s}$ & $(3.17 \mathrm{~s})$ & & & & $3.21 \mathrm{~s}$, & $3.10 \mathrm{~s}$, & & & & & & \\
\hline & $3.22 \mathrm{~s}$ & $(3.22 \mathrm{~s})$ & & & & $3.27 \mathrm{~s}$ & $3.31 \mathrm{~s}$ & & & & & & \\
\hline $\mathrm{H}-1^{\prime}$ & $4.52 \mathrm{~d}$ & $4.55 \mathrm{~d}$ & $1^{\prime}, 2^{\prime}$ & 7.5 & 7.5 & $4.44 \mathrm{~d}$ & $4.49 \mathrm{~d}$ & $1^{\prime}, 2^{\prime}$ & 7.5 & 7.5 & & & \\
\hline$-2^{\prime}$ & $\sim 3.57$ & $3.64 \mathrm{dd}$ & $2^{\prime}, 3^{\prime}$ & & 10 & $\sim 3.57$ & $3.69 \mathrm{dd}$ & $2^{\prime}, 3^{\prime}$ & & 10 & & & \\
\hline$-3^{\prime}$ & $\sim 2.45$ & $2.42 \mathrm{t}$ & $3^{\prime}, 4^{\prime}$ & & 10 & $\sim 2.5$ & 2.4 & $3^{\prime}, 4^{\prime}$ & & 10 & & & \\
\hline$-4^{\prime}$ & 1 & $\sim 3.2$ & $4^{\prime}, 5^{\prime}$ & & 9 & 1 & $\sim 3.2$ & $4^{\prime}, 5^{\prime}$ & & 9 & & & \\
\hline$-5^{\prime}$ & $\{3.2 \sim 3.4$ & $3.0 \mathrm{~m}$ & $5^{\prime}, 6^{\prime}$ & & & $\{3.25 \sim 3.35$ & $2.69 \mathrm{dq}$ & $5^{\prime}, 6^{\prime}$ & 7.5 & & & & \\
\hline $\mathrm{C}\left(5^{\prime}\right)-\mathrm{Me}$ & $1.29 \mathrm{~d}$ & $1.15 \mathrm{~d}$ & & & 7 & $1.29 \mathrm{~d}$ & $1.15 \mathrm{~d}$ & & & & & & \\
\hline $\mathrm{NMe}_{2}$ & $2.51 \mathrm{~s}$ & $2.53 \mathrm{~s}$ & & & & $2.51 \mathrm{~s}$ & $2.56 \mathrm{~s}$ & & & & & & \\
\hline \multirow[t]{2}{*}{$-1^{\prime \prime}$} & $5.08 \mathrm{~d}$ & $4.87 \mathrm{~d}$ & $1^{\prime \prime}, 2^{\prime \prime} \mathrm{a}$ & 3.5 & 3.5 & $5.09 \mathrm{~d}$ & $4.85 \mathrm{~d}$ & $1^{\prime \prime}, 2^{\prime \prime a}$ & 3.5 & 3.5 & & & \\
\hline & & & $1^{\prime \prime}, 2^{\prime \prime} \mathrm{b}=$ & $\simeq 0$ & $\simeq 0$ & & & $1^{\prime \prime}, 2^{\prime \prime} \mathrm{b}$ & $\simeq 0$ & $\simeq 0$ & & & \\
\hline$-2^{\prime \prime} \mathrm{a}$ & $1.84 \mathrm{dd}$ & $1.47 \mathrm{dd}$ & $2^{\prime \prime} \mathrm{a}, 2^{\prime \prime} \mathrm{b}$ & b 14 & 14.5 & $1.85 \mathrm{dd}$ & $1.47 \mathrm{dd}$ & $2^{\prime \prime} \mathrm{a}, 2^{\prime \prime} \mathrm{b}$ & 14 & 14.5 & & & \\
\hline$-2^{\prime \prime} \mathrm{b}$ & $2.02 \mathrm{~d}$ & $1.79 \mathrm{~d}$ & & & & $2.01 \mathrm{~d}$ & $1.79 \mathrm{~d}$ & & & & & & \\
\hline $\mathrm{C}\left(3^{\prime \prime}\right)-\mathrm{Me}$ & $1.12 \mathrm{~s}$ & $1.26 \mathrm{~s}$ & & & & $1.13 \mathrm{~s}$ & $1.28 \mathrm{~s}$ & & & & & & \\
\hline$-4^{\prime \prime}$ & $4.63 \mathrm{~d}$ & $4.90 \mathrm{~d}$ & $4^{\prime \prime}, 5^{\prime \prime}$ & 10 & 10 & $4.63 \mathrm{~d}$ & $4.91 \mathrm{~d}$ & $4^{\prime \prime}, 5^{\prime \prime}$ & 10 & 10 & & & \\
\hline$-5^{\prime \prime}$ & $\sim 4.5$ & $4.71 \mathrm{dq}$ & & & & $\sim 4.5$ & $4.73 \mathrm{dq}$ & $5^{\prime \prime}, \mathrm{Me}$ & & 6 & & & \\
\hline $\mathrm{C}\left(5^{\prime \prime}\right)-\mathrm{Me}$ & $1.14 \mathrm{~d}$ & $1.36 \mathrm{~d}$ & $5^{\prime \prime}, \mathrm{Me}$ & & 7 & $1.15 \mathrm{~d}$ & $1.36 \mathrm{~d}$ & & 7.5 & & & & \\
\hline$-2^{\prime \prime \prime}$ & & $\sim 2.15$ & & & & $2.3 \mathrm{~d}$ & $\sim 2.16$ & & & & & & \\
\hline$-3^{\prime \prime \prime}$ & $\sim 2.2$ & $\sim 2.18$ & & & & $\sim 2.1(?)$ & $\sim 2.35$ & & & & & & \\
\hline \multirow[t]{2}{*}{$\mathrm{C}\left(3^{\prime \prime \prime}\right)-\mathrm{Me}_{2}$} & $0.95 \mathrm{~d}$ & $0.85 \mathrm{~d}$ & & 7 & 7 & $0.98 \mathrm{~d}$ & $0.86 \mathrm{~d}$ & & 7 & 7 & & & \\
\hline & $0.98 \mathrm{~d}$ & $0.87 \mathrm{~d}$ & & 7 & 7 & & $0.87 \mathrm{~d}$ & & & 7 & & & \\
\hline
\end{tabular}

*1 Dihedral angle formed, for example, by $\mathrm{H}-\mathrm{C}_{2 \mathrm{a}}$ and $\mathrm{C}_{3}-\mathrm{H}$ in a $\mathrm{H}-\mathrm{C}_{2 \mathrm{a}}-\mathrm{C}_{3}-\mathrm{H}$ system (the H's involved are cited in the column of $\mathrm{H}$, $\mathrm{H}$ ).

*2 $J$ values calculated by the angles cited in the left column.

*3 Tentatively assigned. 
peared as an unresolved multiplet ( $\delta$ 5.04). On irradiation at C(15)-Me, the multiplet became a sharp doublet indicating that $J_{14 \mathrm{a}, 15}$ and $J_{14 \mathrm{~b}, 15}$ should be 9.5 and $\simeq 0 \mathrm{~Hz}$. It may be interesting to find the mixture-point of $\mathrm{CDCl}_{3}-\mathrm{C}_{6} \mathrm{D}_{8}$, at which the above change in $J_{14,15}$ value will occur. This was found to be at the mixture between 10:1 5: 1 of $\mathrm{CDCl}_{3}-\mathrm{C}_{6} \mathrm{D}_{6}$. In the former mixture (10: 1), $\mathrm{H}-15(\delta 5.04)$ appeared in the same pattern as observed in chloroform- $d$, but in the latter mixture, H-15 appeared as an unresolved multiplet ( $\delta 4.98$ ) similar to that observed in $\mathrm{C}_{6} \mathrm{D}_{6}$. Gradual increase in the ratio of $\mathrm{C}_{6} \mathrm{D}_{6}$ gave no further change in the pattern of $\mathrm{H}-15$. On the signals of $\mathrm{H}-13$, similar change in $J$ values were also observed.

\section{Experimental}

\section{General}

Thin-layer chromatography (TLC) was carried out on precoated silica gel HPTLC $60 \mathrm{~F}_{254}$ (E. Merck, Darmstadt) with benzene - acetone (3:1), unless otherwise stated, with detection by spraying with sulfuric acid, followed by slight heating. Column chromatography was performed on Kieselgel 60, $230 \sim 400$ mesh (E. Merck), or on Kieselgel 60 prepacked column for LC, size B (E. Merck) (Column A) unless otherwise stated. ${ }^{1} \mathrm{H}$ NMR spectra were recorded at $90 \mathrm{MHz}$ with a Varian EM-390 spectrometer or at $250 \mathrm{MHz}$ with a Bruker WM 250 spectrometer.

A Mixture of 9-O-Methyljosamycin Dimethylacetal (1) and 13-O-Methylisojosamycin Dimethylacetal (2)

A solution of josamycin ( $258 \mathrm{mg}$ as base) and anhydrous p-toluenesulfonic acid ( $80 \mathrm{mg}$ ) in dry methanol $(2.6 \mathrm{ml})$ was kept in an ice-bath for 12 hours. Triethylamine $(63 \mathrm{mg})$ was added and the solution was concentrated in vacuo. The residue was dissolved in chloroform (15 ml) and the solution was washed with saturated aqueous sodium hydrogen carbonate, water, dried over sodium sulfate, and evaporated. The residue showed, on TLC, spots of Rf 0.91 (trace) and 0.73 (trace) [methyl 4-Oisovaleryl- $\alpha$ - and - $\beta$-mycarosides (3 and 4), respectively], 0.42 (major, 1 and 2), 0.26 (trace, josamycin dimethylacetal (5)], 0.2 (trace, josamycin) and 0.1 (minor, 9- $O$-methyldemycarosyljosamycin dimethylacetal and 13-O-methyldemycarosylisojosamycin dimethylacetal ${ }^{4)}$ ?). Separation by column chromatography gave a mixture of $\mathbf{1}$ and $\mathbf{2}, 183 \mathrm{mg}(66 \%)$.

Treatment of josamycin in a similar manner changing only the temperature $\left(20^{\circ} \mathrm{C}, 12\right.$ hours $)$ gave, after column chromatography, $\mathbf{3}$ and $\mathbf{4}$ in better yields than those obtained in the former experiment to give thick syrups ( 25 and $50 \%$, respectively).

3: $[\alpha]_{D}^{15}-137^{\circ}$ (c 2, chloroform) $\left[\right.$ Ref. $^{5,6)}-135^{\circ}$ (c 1.33, chloroform)]. ${ }^{1} \mathrm{H}$ NMR (in $\mathrm{CDCl}_{3}$ at $250 \mathrm{MHz}): \delta 0.98\left(6 \mathrm{H} \mathrm{d}, \mathrm{C}\left(3^{\prime}\right)-\mathrm{Me}_{2}\right), 1.11(3 \mathrm{H} \mathrm{s}, \mathrm{C}(3)-\mathrm{Me}), 1.18(3 \mathrm{H} \mathrm{d}, \mathrm{C}(5)-\mathrm{Me}), 1.88\left(1 \mathrm{H} \mathrm{dd}, J_{1,2_{\mathrm{ax}}}\right.$ $\left.4 \mathrm{~Hz}, J_{2,2} 15 \mathrm{~Hz}, \mathrm{H}-2_{\mathrm{ax}}\right), 2.01\left(1 \mathrm{H} \mathrm{dd}, J_{1,2 \mathrm{eq}} \simeq 1 \mathrm{~Hz}, \mathrm{H}-2_{\mathrm{eq}}\right), 2.15(1 \mathrm{H} \mathrm{m}, \mathrm{H}-3$ ') $2.295(1 \mathrm{H} \mathrm{d}, J 6 \mathrm{~Hz})$ and $2.300\left(2 \mathrm{H}, \mathrm{d}, J 8 \mathrm{~Hz}, \mathrm{COCH}_{2} \mathrm{CH}\right), 3.39(3 \mathrm{H} \mathrm{s}, \mathrm{OMe}), 4.00(1 \mathrm{H} \mathrm{dq}, \mathrm{H}-5), 4.65\left(1 \mathrm{H} \mathrm{d}, J_{4,5} 10 \mathrm{~Hz}\right.$, $\mathrm{H}-4), 4.80$ (1 $\mathrm{H}$ slightly broadened $\mathrm{d}, \mathrm{H}-1)$. Irradiation of $\mathrm{C}\left(3^{\prime}\right)-\mathrm{Me}_{2}$ collapsed the multiplet of $\mathrm{H}-3^{\prime}$ to an apparent triplet $(J 7 \mathrm{~Hz})$.

4: $[\alpha]_{D}^{15}+14^{\circ}$ (c 3, chloroform) $\left[\operatorname{Ref}^{5,6)}+13.5^{\circ}\right.$ (c 1.33, chloroform)]. ${ }^{1} \mathrm{H}$ NMR (in $\mathrm{CDCl}_{3}$ at $250 \mathrm{MHz}): \delta 0.99(6 \mathrm{H} \mathrm{d}), 1.15(3 \mathrm{H} \mathrm{s}), 1.18(3 \mathrm{H} \mathrm{d}), 1.62\left(1 \mathrm{H} \mathrm{ddd}, J_{1,2 \mathrm{ax}} 10 \mathrm{~Hz}, J_{2,2} 15 \mathrm{~Hz}, J_{2 \mathrm{ax}, 3 \text { - О }}\right.$ $2.5 \mathrm{~Hz}, \mathrm{H}-2_{\mathrm{ax}}$; became dd on deuteration), $1.82(1 \mathrm{H} \mathrm{d}$, disappeared on deuteration, HO-3), $2.02(1 \mathrm{H}$ dd, $\left.J_{1,2 \mathrm{eq}} 2.5 \mathrm{~Hz}, \mathrm{H}-2_{\mathrm{eq}}\right), 2.15(1 \mathrm{H} \mathrm{m}), 2.275(1 \mathrm{H} \mathrm{d}, J 6 \mathrm{~Hz}), 2.280(1 \mathrm{H} \mathrm{d}, J 8 \mathrm{~Hz}), 2.49(\mathrm{OMe}), 3.85$ (H-5), 4.63 (H-4), 4.73 (1H dd, H-1).

To obtain josamycin dimethylacetal (5) in better yield, josamycin was likewise treated for 5 hours in an ice-bath, whereupon 5 was isolated, after column chromatography, in $25 \%$ yield, $[\alpha]_{D}^{21}-66^{\circ}(c$ 1, ethanol) $\left[\operatorname{Ref}^{7)}-64.0^{\circ}\right.$ (c 1.0, ethanol)].

${ }^{1} \mathrm{H}$ NMR (in $\mathrm{CDCl}_{3}$ at $250 \mathrm{MHz}$ ): $\delta 2.12(3 \mathrm{H} \mathrm{s}, \mathrm{Ac}), 2.51\left(6 \mathrm{H} \mathrm{s}, \mathrm{NMe}_{2}\right), 3.21$ and 3.28 [each $3 \mathrm{H}$ s, $\left.\mathrm{CH}(\mathrm{OMe})_{2}\right], 3.55$ (3H s, C(4)-OMe), $4.20(1 \mathrm{H} \mathrm{dd}, \mathrm{H}-9), 5.65(1 \mathrm{H} \mathrm{dd}, \mathrm{H}-10), 5.74(1 \mathrm{H} \mathrm{ddd}, \mathrm{H}-13)$, $6.07(1 \mathrm{H} \mathrm{dd}, \mathrm{H}-12), 6.53(1 \mathrm{H} \mathrm{dd}, \mathrm{H}-11) . \quad J_{8,9} 4.5, J_{9,10} 10, J_{10,11} 16, J_{11,12} 11, J_{12,13} 15 \mathrm{~Hz} ; J_{13,14 a}$, $J_{13,14 \mathrm{~b}}, 3.5$ and $11 \mathrm{~Hz}$. 


\section{Separation of $\mathbf{1}$ and $\mathbf{2}$}

A mixture $(1.76 \mathrm{~g})$ of $\mathbf{1}$ and $\mathbf{2}$ was chromatographed on a column of silica gel with benzene hexane $(1: 1) \rightarrow$ benzene - hexane - acetone (4:4:3) (gradually changed). From the earlier and the later fractions, a mixture of $\mathbf{1}$ and $\mathbf{2}$ which was rich in $\mathbf{1}(0.54 \mathrm{~g})$ and a mixture of $\mathbf{1}$ and $\mathbf{2}(0.98 \mathrm{~g})$ were obtained, respectively. The former and the latter mixtures were, separately, chromatographed twice more on "Column A" with benzene - hexane - acetone (2:2:1) to afford pure $1(183 \mathrm{mg})$ and pure $2(310 \mathrm{mg})$.

${ }^{1} \mathrm{H}$ NMR of 2 (in $\mathrm{CDCl}_{3}$ at $250 \mathrm{MHz}$ ): Irradiation at $\delta 4.99(\mathrm{H}-15)$ caused the doublet of $\mathrm{C}(15) \mathrm{Me}$ and the triplet of $\mathrm{H}-14$ to collapse to a singlet and a doublet $(\mathrm{J} 7.5 \mathrm{~Hz})$, respectively. Irradiation at $\delta 1.88$ (H-14, H-2"a) caused the multiplet (sextet) of $\mathrm{H}-15$ and the doublet of $\mathrm{H}-1^{\prime \prime}$ to collapse to a quartet $(J 7.5 \mathrm{~Hz})$ and a singlet, respectively. Irradiation at $\delta 3.56\left(\mathrm{H}-13,2^{\prime}, \mathrm{MeO}-13\right)$ caused the triplet of $\mathrm{H}-14$, quartet of $\mathrm{H}-12$, and the doublet of $\mathrm{H}^{-1}{ }^{\prime}$ to collapse to a doublet $(J 7.5 \mathrm{~Hz})$, a doublet $(J 15 \mathrm{~Hz})$, and a singlet, respectively. Irradiation of $\mathrm{H}-12$ caused the quartet of $\mathrm{H}-11$ to collapse to a doublet. Irradiation at $\delta 6.22(\mathrm{H}-11,9$ and partially 10$)$ caused the quartet of $\mathrm{H}-12$ to collapse to a doublet $(J 9 \mathrm{~Hz})$. Irradiation at $\delta 2.3\left(\mathrm{H}-8\right.$ and $\left.\mathrm{COCH}_{2}-\right)$ caused the doublet of $\mathrm{C}(8) \mathrm{Me}$; the quartet of H-9, and the double triplets of $\mathrm{H}-7 \mathrm{~b}$ to collapse to a singlet, a doublet $(J 15 \mathrm{~Hz})$, and a triplet $(J \simeq$ $12.5 \mathrm{~Hz}$ ), respectively. Irradiation at $\delta 1.2(\mathrm{H}-7 \mathrm{a})$ caused the double triplets of $\mathrm{H}-7 \mathrm{~b}$ to collapse to a broadened doublet. Irradiation of $\mathrm{H}-7 \mathrm{~b}$ caused the signals between $\delta 1.6 \sim 1.7$ to change and the doublet of H-5 to sharpen. Irradiation at 1.6 1.7 (H-6, 17a, 17b) caused the double triplets of H-7b to collapse to a doublet. Irradiation of H-5 caused the signals at $\delta \sim 3.2$ to change. Irradiation of H-4 collapsed the doublet of $\mathrm{H}-5$ to a singlet, and the slightly broadened doublet of $\mathrm{H}-3$ to a sharp doublet. Irradiation of H-3 collapsed the double doublets of $\mathrm{H}-2 \mathrm{~b}$ to a doublet $(J 15 \mathrm{~Hz})$, but no change was observed for the doublet of $\mathrm{H}-2 \mathrm{a}$ by the irradiation. By this irradiation, a small doublet $\left(J_{3,4} \simeq 1.5 \mathrm{~Hz}\right)$ at $\delta 3.18$ became a singlet. Irradiation of $\mathrm{H}-2 \mathrm{~b}$ collapsed the doublet of $\mathrm{H}-2 \mathrm{a}$ and that of $\mathrm{H}-3$ to a singlet, respectively. Irradiation at $\delta 4.48\left(\mathrm{H}-18,1^{\prime}, 5^{\prime \prime}\right)$ caused the multiplet at $\delta 1.55 \sim 1.85$ to change. By this irradiation the doublet of $\mathrm{H}-4^{\prime \prime}$ and that of $\mathrm{C}\left(5^{\prime \prime}\right)$-Me also collapsed to a singlet, respectively.

${ }^{1} \mathrm{H}$ NMR of 2 (in 10: 1, $\mathrm{CDCl}_{3}-\mathrm{C}_{6} \mathrm{D}_{6}$ at $250 \mathrm{MHz}$ ): Irradiation at $\delta 5.04(\mathrm{H}-15)$ caused the triplet of $\mathrm{H}-14\left(\delta 1.94, J_{13,14} 7 \mathrm{~Hz}\right)$ to collapse to a doublet.

${ }^{1} \mathrm{H}$ NMR of 2 (in 1: 1, $\mathrm{CDCl}_{3}-\mathrm{C}_{6} \mathrm{D}_{6}$ at $250 \mathrm{MHz}$ ): Signals of $\mathrm{H}-13$ appeared at $\delta 3.48$ as double triplets $\left(J_{12,13}=J_{13,14 \mathrm{~b}} \simeq 9.5 \mathrm{~Hz}, J_{13,14 \mathrm{a}} \simeq 3.3 \mathrm{~Hz}\right)$ without overlapping with other signals. Irradiation at $\delta 1.83(\mathrm{H}-14 \mathrm{a})$ collapsed the double triplets of $\mathrm{H}-13$ to double doublets.

A Mixture of 9-O-Ethyljosamycin Diethylacetal (10) and 13-O-Ethylisojosamycin Diethylacetal (11)

A solution of josamycin $(2.19 \mathrm{~g})$ and anhydrous $p$-toluenesulfonic acid $(685 \mathrm{mg})$ in dry ethanol $(22 \mathrm{ml})$ was kept in an ice-bath. After 1 hour, on checking by TLC, josamycin (Rf 0.2) almost disappeared and josamycin diethylacetal (14) was the major product. After 24 hours, the reaction mixture showed, on TLC, spots of Rf 0.92 and 0.75 [ethyl 4- $O$-isovaleryl- $\alpha$ - and - $\beta$-mycarosides (12 and 13), respectively], 0.46 (major, 10 and 11), 0.29 (14), 0.12 [a mixture of 9- $O$-ethyl-de(mycarosyl)josamycin diethylacetal (15) and 13-O-ethyl-de(mycarosyl)isojosamycin diethylacetal (16)] and 0.04 [de(mycarosyl)josamycin diethylacetal (17)]. After addition of triethylamine $(0.7 \mathrm{ml})$, the reaction mixture was worked up as described for $\mathbf{1}$ and $\mathbf{2}$ and the crude product was subjected to column chromatography (silica gel was charged with benzene) with benzene - ethanol $(20: 1 \rightarrow 6: 1$, gradually changed, finally with $3: 1)$.

12: $65 \mathrm{mg}(9 \%)$, thick syrup, $[\alpha]_{\mathrm{D}}^{15}-123^{\circ}$ (c 1, chloroform). ${ }^{1} \mathrm{H}$ NMR (in $\mathrm{CDCl}_{3}$ at $250 \mathrm{MHz}$ ): $\delta 3.47$ and 3.78 (each $1 \mathrm{H} \mathrm{dq}, J 7$ and $\left.10 \mathrm{~Hz}, \mathrm{CH}_{2} \mathrm{CH}_{2} \mathrm{O}-\right), 4.05(1 \mathrm{H} \mathrm{m}, \mathrm{H}-5), 4.66\left(1 \mathrm{H} \mathrm{d}, J_{4,5} 10 \mathrm{~Hz}\right.$, $\mathrm{H}-4), 4.92$ (1H slightly broadened $\mathrm{d}, \mathrm{H}-1)$.

Anal. Calcd. for $\mathrm{C}_{14} \mathrm{H}_{28} \mathrm{O}_{5}$ : Found:

C, $61.29 ; \mathrm{H}, 9.55$.

C, $61.35 ; \mathrm{H}, 9.41$.

13: $200 \mathrm{mg}(28 \%)$, m.p. $35.5 \sim 37^{\circ} \mathrm{C},[\alpha]_{\mathrm{D}}^{15}+15^{\circ}$ (c 1, chloroform). ${ }^{1} \mathrm{H}$ NMR (in $\mathrm{CDCl}_{3}$ at $250 \mathrm{MHz}): \delta 3.55$ and $3.94\left(\mathrm{CH}_{3} \mathrm{CH}_{2} \mathrm{O}-\right), 4.84(1 \mathrm{H} \mathrm{dd}, J 2.5$ and $9.5 \mathrm{~Hz}, \mathrm{H}-1)$. 

Anal. Calcd. for $\mathrm{C}_{14} \mathrm{H}_{26} \mathrm{O}_{5}$ :
C, $61.29 ; \mathrm{H}, 9.55$.
Found:
C, $61.23 ; \mathrm{H}, 9.38$.

A mixture of 10 and 11, $1.16 \mathrm{~g}\left(47 \%\right.$ ). ${ }^{1} \mathrm{H} \mathrm{NMR} \mathrm{(in} \mathrm{CDCl}_{3}$ at $250 \mathrm{MHz}$ ): $\delta 2.07$ (s, Ac for 11), 2.11 (s, Ac for 10), 2.50 (s, $\mathrm{NMe}_{2}$ for 11), 2.51 (s, NMe $\mathrm{N}_{2}$ for 10), 3.55 (3H s, C(4)-OMe).

14: $250 \mathrm{mg}(11 \%) .{ }^{1} \mathrm{H} \mathrm{NMR}$ (in $\mathrm{CDCl}_{3}$ at $\left.250 \mathrm{MHz}\right): \delta 2.10(3 \mathrm{H} \mathrm{s}, \mathrm{Ac}), 2.50\left(6 \mathrm{H} \mathrm{s}, \mathrm{NMe}_{2}\right)$, 3.55 (3H s, C(4)-OMe), 4.23 (1H dd, H-9). The signal pattern for the olefin protons was almost the same with that of $\mathbf{5}$.

A mixture of 15 and 16, $457 \mathrm{mg}(25 \%)$, amorphous powder, $[\alpha]_{D}^{15}-19^{\circ}$ (c 1, chloroform). ${ }^{1} \mathrm{H}$ NMR (in $\mathrm{CDCl}_{3}$ at $250 \mathrm{MHz}$ ): $\delta 2.08$ (s, Ac for 16), 2.12 (s, Ac for 15), $2.56\left(6 \mathrm{H} \mathrm{s}, \mathrm{NMe}_{2}\right.$ ), $3.55(3 \mathrm{H}$ s, MeO-4).

Anal. Calcd. for $\mathrm{C}_{38} \mathrm{H}_{63} \mathrm{NO}_{12}$ : C, 61.60; H, 9.05; N, 2.10 .
Found:
C, 61.31; H, 8.79; N, 1.90 .

17: $161 \mathrm{mg}(9 \%)$, amorphous powder $[\alpha]_{\mathrm{D}}^{15}-6^{\circ}$ (c 1, chloroform). ${ }^{1} \mathrm{H} \mathrm{NMR}\left(\mathrm{CDCl}_{3}\right): \delta 2.10$ (Ac), $2.55\left(\mathrm{NMe}_{2}\right), 3.55$ (C(4)-OMe), 4.24 (dd, H-9), 4.52 (1H dd, $J_{17 \mathrm{a}, 18}, J_{17 \mathrm{~b}, 18} 3.8$ and 7.5 Hz, H-18), 4.57 (1H d, $\left.J_{1^{\prime}, 2^{\prime}} 7.5 \mathrm{~Hz}, \mathrm{H}-1^{\prime}\right), 4.97 \sim 5.1(2 \mathrm{H}, \mathrm{H}-3,-15), 5.67$ (1H dd, H-10), 5.73 (1H ddd, H-13), 6.06 (1H dd, H-12), 6.49 (1H dd, H-11).

$\begin{array}{ll}\text { Anal. Calcd. for } \mathrm{C}_{34} \mathrm{H}_{59} \mathrm{NO}_{12}: & \mathrm{C}, 60.60 ; \mathrm{H}, 8.83 ; \mathrm{N}, 2.08 . \\ \begin{array}{ll}\text { Found: } & \text { C, } 60.74 ; \mathrm{H}, 8.80 ; \mathrm{N}, 2.17 .\end{array}\end{array}$

A Mixture of 9-O-Propyljosamycin Dipropylacetal (24) and 13-O-Propylisojosamycin Dipropylacetal (25)

A mixture of josamycin (478 mg) and anhydrous $p$-toluenesulfonic acid $(150 \mathrm{mg})$ in dry propanol $(8 \mathrm{ml})$ was kept in an ice-bath for 24 hours. After usual work-up, products were isolated.

Propyl 4- $O$-isovaleryl- $\alpha$-mycaroside (26), $12 \mathrm{mg}\left(7 \%\right.$ ), thick syrup, $[\alpha]_{\mathrm{D}}^{15}-119^{\circ}$ (c 1, chloroform). ${ }^{1} \mathrm{H} \mathrm{NMR}$ (in $\mathrm{CDCl}_{3}$ at $250 \mathrm{MHz}$ ): $\delta 3.36$ and 3.68 (each $1 \mathrm{H} \mathrm{dt}, J 7$ and $10 \mathrm{~Hz}, \mathrm{CH}_{3} \mathrm{CH}_{2} \mathrm{CH}_{2} \mathrm{O}-$ ), 4.91 (1H d, H-1).
Anal. Calcd. for $\mathrm{C}_{15} \mathrm{H}_{25} \mathrm{O}_{5}$ :
C, 62.47; H, 9.79.
Found:
C, 62.42; H, 9.58 .

Propyl 4-O-isovaleryl- $\beta$-mycaroside (27), $54 \mathrm{mg}(32 \%)$, thick syrup, $[\alpha]_{\mathrm{D}}^{15}+15^{\circ}$ (c 1 , chloroform). ${ }^{1} \mathrm{H} \mathrm{NMR}$ (in $\mathrm{CDCl}_{3}$ at $250 \mathrm{MHz}$ ): $\delta 3.41$ and 3.82 (each $1 \mathrm{H} \mathrm{dt}, J 7$ and $10 \mathrm{~Hz}, \mathrm{CH}_{3} \mathrm{CH}_{2} \mathrm{CH}_{2} \mathrm{O}-$ ), 4.82 (1H dd, H-1).

Anal. Found: C, 62.27; H, 9.52.

A mixture of 24 and 25, $149 \mathrm{mg}\left(28 \%\right.$ ). ${ }^{1} \mathrm{H} \mathrm{NMR} \mathrm{(in} \mathrm{CDCl}_{3}$ at $250 \mathrm{MHz}$ ): 2.07 (s, Ac for 25), 2.11 (s, Ac for 24), 2.50 (s, $\mathrm{NMe}_{2}$ for 25), 2.51 (s, $\mathrm{NMe}_{2}$ for 24), 3.56 (3H s, C(4)-OMe).

Josamycin dipropylacetal (28), $65 \mathrm{mg}(12 \%) .{ }^{1} \mathrm{H} \mathrm{NMR}$ (in $\mathrm{CDCl}_{3}$ at $\left.250 \mathrm{MHz}\right): \delta 2.10(3 \mathrm{H} \mathrm{s}$, Ac), 2.51 (6H s, $\left.\mathrm{NMe}_{2}\right), 3.56$ (3H s, C(4)-OMe).

A Mixture of 9-O-Butyljosamycin Dibutylacetal (33) and 13-O-Butylisojosamycin Dibutylacetal (34)

Josamycin (441 mg) was similarly treated in $n$-butanol $(4.4 \mathrm{ml})$ containing $p$-toluenesulfonic acid (140 mg) in an ice-bath for 24 hours in a manner as described above to give a mixture of 33 and $\mathbf{3 4}$, $75 \mathrm{mg}(14 \%)$ and josamycin dibutylacetal (35), $61 \mathrm{mg}(12 \%) .{ }^{1} \mathrm{H} \mathrm{NMR}$ (in $\mathrm{CDCl}_{3}$ at $250 \mathrm{MHz}$ ) of the mixture of 33 and 34: $\delta 2.07$ (Ac for 34), 2.10 (Ac for 33).

9-O-Ethyljosamycin (20) and 13-O-Ethylisojosamycin (21)

A mixture of josamycin $(1.93 \mathrm{~g})$, dry ethanol $(1.56 \mathrm{ml})$ and trifluoroacetic acid $(0.27 \mathrm{ml})$ in dry acetonitrile $(20 \mathrm{ml})$ was allowed to stand at room temperature for 30 days. The reaction mixture showed, on TLC, 7 spots of 0.46 (a mixture of 10 and 11), 0.44 (20), 0.40 (21), 0.29 (14), 0.2 (josamycin), 0.12 and 0.04 . Usual work-up as described above gave a crude mixture, which was chromatographed on a column of silica gel with benzene $\rightarrow$ benzene - acetone (3:1) (gradually changed) to give a pure mixture of $\mathbf{2 0}$ and 21. Chromatography of the mixture by "Column A" with benzene - acetone (4: 1) gave 21, $34 \mathrm{mg}(1.7 \%)$ and the fractions containing 20 mainly. The latter was again chromatographed on "Column A" with benzene - hexane - acetone $(2: 1: 1)$ and the fractions containing 20 was further chromatographed on Sephadex LH-20 (developed with methanol) to give pure 20, $34 \mathrm{mg}(1.7 \%)$.

${ }^{1} \mathrm{H} \mathrm{NMR}\left(\mathrm{CDCl}_{3}\right) . \quad 20: \delta 2.13(3 \mathrm{H} \mathrm{s}, \mathrm{Ac}), 2.56\left(6 \mathrm{H} \mathrm{s}, \mathrm{NMe}_{2}\right), 3.57(3 \mathrm{H} \mathrm{s}, \mathrm{C}(4)-\mathrm{OMe}), 9.72(1 \mathrm{H} \mathrm{s}$, 
CHO). Olefin protons assignable to $\mathrm{H}-10,11,12$ and 13 gave almost the same $\delta$ and $J$ values with those of 1 .

21: $\delta 2.09(3 \mathrm{H} \mathrm{s}, \mathrm{Ac}), 2.55\left(6 \mathrm{H} \mathrm{s}, \mathrm{NMe}_{2}\right), 3.60(3 \mathrm{H} \mathrm{s}, \mathrm{C}(4)-\mathrm{OMe}), 9.72(1 \mathrm{H} \mathrm{s}, \mathrm{CHO}) . \quad$ Olefin protons assignable to $\mathrm{H}-9,10,11$ and 12 gave almost the same $\delta$ and $J$ values with those of 2 .

A Mixture of 9-O-Isopropyljosamycin (40) and 13-O-Isopropylisojosamycin (41)

A solution of josamycin $(620 \mathrm{mg})$ and $p$-toluenesulfonic acid $(190 \mathrm{mg})$ in dry isopropanol $(6 \mathrm{ml})$ was kept at room temperature for 7 hours, then triethylamine $(150 \mathrm{mg})$ was added to stop the reaction. On checking by TLC, the solution showed spots of $\mathrm{Rf} 0.35$ and 0.38 ( $\sim 3: 1$ in strength) (40 and 41, major), 0.2 (josamycin). Several other spots were also observed. Silica gel column chromatography with benzene - acetone (4:1) gave a mixture of 40 and $41,52 \mathrm{mg}(8 \%)$.

${ }^{1} \mathrm{H}$ NMR $\left(\mathrm{CDCl}_{3}\right): \delta 2.27$ (s, Ac for 41) and 2.31 (s, Ac for 40 ) (3H in total), 2.55 (6H s, $\mathrm{NMe}_{2}$ ), 3.59 (s, C(4)-OMe for 40) and 3.61 (s, C(4)-OMe for 41$), 9.77(1 \mathrm{H} \mathrm{s}, \mathrm{CHO})$. The signal pattern ascribed to olefin protons resembled that of $\mathbf{1}$ more than that of $\mathbf{2}$.

9- $O$-( $t$-Butyl)josamycin (42) and 13-O-( $t$-Butyl)isojosamycin (43)

A solution of josamycin $(1.07 \mathrm{~g})$ in dry acetonitrile $(10 \mathrm{ml})$ containing $t$-butanol $(2.3 \mathrm{ml})$ and trifluoroacetic acid $(0.18 \mathrm{ml})$ was kept at room temperature for 75 hours. The reaction mixture contained 42 ( $R f$ 0.41), 43 ( Rf 0.37), josamycin ( Rf 0.2) and other minor products. Separation by column chromatography gave pure $\mathbf{4 2}, 17.5 \mathrm{mg}(1.5 \%)$ and a mixture of $\mathbf{4 2}$ and $\mathbf{4 3}, 46 \mathrm{mg}(8.4 \%)$.

${ }^{1} \mathrm{H} \mathrm{NMR}\left(\mathrm{CDCl}_{3}\right)$ of $42: 2.30(3 \mathrm{H} \mathrm{s}, \mathrm{Ac}), 2.56\left(6 \mathrm{H} \mathrm{s}, \mathrm{NMe}_{2}\right), 3.59(3 \mathrm{H} \mathrm{s}, \mathrm{C}(4)-\mathrm{OMe}), 9.76(1 \mathrm{H} \mathrm{s}$, $\mathrm{CHO})$.

9-O-(2-Cyanoethyl)josamycin (44) and 13-O-(2-Cyanoethyl)isojosamycin (45)

To a solution of josamycin $(1.52 \mathrm{~g})$ in dry acetonitrile $(15 \mathrm{ml})$ was added 2-cyanoethanol $(1.25 \mathrm{ml})$ and trifluoroacetic acid $(410 \mathrm{mg})$, and the mixture was kept at room temperature for 2.5 hours. Usual

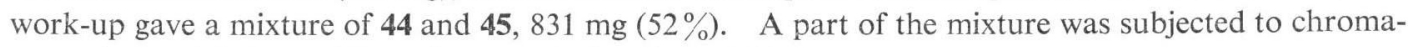
tography on "Column A" to give pure $\mathbf{4 4}$ in a low yield.

${ }^{1} \mathrm{H}$ NMR of $44\left(\mathrm{CDCl}_{3}\right): \delta 2.33(\mathrm{Ac}), 2.57\left(\mathrm{NMe}_{2}\right), 3.60$ (C(4)-OMe), $9.77(\mathrm{CHO})$.

9-O-Phenyljosamycin (46) and 13-O-Phenylisojosamycin (47)

A solution of josamycin $(2.05 \mathrm{~g})$ in dry acetonitrile $(20 \mathrm{ml})$ containing phenol $(4.7 \mathrm{ml})$ and trifluoroacetic acid $(0.19 \mathrm{ml})$ was kept at room temperature for 30 hours. The solution showed, after addition of triethylamine, 4 spots of Rf 0.44 (46, minor), 0.32 (47, major), 0.2 (josamycin, slight) and 0.04. Separation by column chromatography with benzene - acetone $(4: 1)$ gave $46,197 \mathrm{mg}(9 \%)$ and $47,933 \mathrm{mg}(42 \%)$.

${ }^{1} \mathrm{H}$ NMR $\left(\mathrm{CDCl}_{3}\right), 46: \delta 2.34(\mathrm{Ac}), 2.58\left(\mathrm{NMe}_{2}\right), 3.60$ (C(4)-OMe), $9.77(\mathrm{CHO}) . \quad 47: 2.28$ (Ac), $2.58\left(\mathrm{NMe}_{2}\right), 3.65(\mathrm{C}(4)-\mathrm{OMe}), 9.77(\mathrm{CHO})$.

9-(1-Methyl-1 $H$-tetrazol-5-ylthio)josamycin (48) and 13-(1-Methyl-1 $H$-tetrazol-5-ylthio)isojosamycin (49)

To a solution of josamycin $(244 \mathrm{mg})$ in acetonitrile $(2.4 \mathrm{ml})$ was added 1-methyl- $1 \mathrm{H}$-tetrazol-5ylthiol $(58 \mathrm{mg})$ and trifluoroacetic acid $(62 \mathrm{mg})$, and the mixture was kept at room temperature for 20 hours. The solution, after addition of triethylamine $(0.11 \mathrm{ml})$, showed, on TLC, spots of 0.39 (48), 0.35 (49) and 0.2 (josamycin). Silica gel column chromatography with benzene - acetone (4:1) gave $48,62.5 \mathrm{mg}(15 \%)$ and $49,84 \mathrm{mg}(33 \%)$.

${ }^{1} \mathrm{H}$ NMR $\left(\mathrm{CDCl}_{3}\right), 48: \delta 2.32$ (Ac), $2.55\left(\mathrm{NMe}_{2}\right), 3.59$ (C(4)-OMe), $3.94(\mathrm{NMe}), 9.82$ (CHO). 49: 2.23 (Ac), $2.55\left(\mathrm{NMe}_{2}\right), 3.61(\mathrm{C}(4)-\mathrm{OMe}), 3.94(\mathrm{NMe}), 9.72(\mathrm{CHO})$.

General Procedure for Hydrogenation of Diene Compounds (1, 2, 10, 11, 24, 25, 33 and 34)

Starting diene compound ( $\mathrm{ca} .0 .5$ mmole) dissolved in methanol [10 $\mathrm{ml}$ (in the cases of $\mathbb{1}$ and 2)] or ethanol (10 $\mathrm{ml}$, for the other compounds) was hydrogenated under the atmospheric pressure of hydrogen in the presence of palladium black for 1 hour. The products showed, on TLC, the same $\mathrm{Rf}$ values with those of the corresponding starting materials, respectively, but, unlike the starting materials, the spots can not be detected under the UV light [Super-light LS-D1 (2537 $\AA$ ), Nikko Sekiei Works, Japan]. The reaction mixture was filtered and concentrated to give the corresponding 9-O- 
alkyltetrahydrojosamycin dialkylacetal $(6,18,29,36)$ and 13-O-alkyltetrahydroisojosamycin dialkylacetal $(7,19,30$ and 37$)$. They were obtained quantitatively in all cases. In their ${ }^{1} \mathrm{H}$ NMR spectra, signals for olefin protons had disappeared.

General Procedure for Deacetalation of 9-O-Alkyltetrahydrojosamycin Dialkylacetals $(6,18,29$ and 36) and 13-O-Alkyltetrahydroisojosamycin Dialkylacetals (7, 19, 30 and 37).

To a solution of starting tetrahydroacetal $(c a .0 .5 \mathrm{mmole})$ dissolved in acetonitrile $(10 \mathrm{ml})$ was added $0.05 \mathrm{M}$ hydrochloric acid $(15 \mathrm{ml})$ under cooling and the solution was kept at $20^{\circ} \mathrm{C}$ for 18 hours (for 6 and 7), 24 hours (for 18 and 19), 50 hours (for 29 and 30) or 120 hours (for 36 and 37). The reaction mixture showed, on checking by TLC with benzene - acetone (3:1) or benzene - methanol (10:1) (for 6 and 7), major spots at the Rf values slightly smaller than those of the corresponding starting materials. Some other slight spots ascribable to by-products were also observed. The reaction periods mentioned above were determined in order to give the biggest spots, on TLC, of the deacetalation products, respectively. After working up in a usual manner, the crude products obtained were purified by column chromatography with benzene - acetone $(5: 1)$ or $4: 1$ (for 6 and 7). The yields of deacetalation products were as follows: $8(40 \%), 9(40 \%)$, a mixture of 22 and $23(80 \%)$, a mixture of $\mathbf{3 1}$ and $\mathbf{3 2}(49 \%)$ and a mixture of $\mathbf{3 8}$ and $\mathbf{3 9}(38 \%)$; the above fluctuation in yields being, in part, ascribable to the ease or difficulty of the purification by column chromatography. In their ${ }^{1} \mathrm{H}$ NMR spectra, aldehyde protons appeared at $\delta \simeq 9.77$ as $1 \mathrm{H}$ singlets in all cases.

\section{Acknowledgement}

The authors thank Dr. TAKASH Osono of Yamanouchi Pharmaceutical Co., Ltd. for valuable discussions. We also thank Mr. SABURo NAKADA of Keio University for elemental analysis. Thanks are also due to Miss MiYaKo IgARASH of Institute of Bioorganic Chemistry for her helpful assistance to make the manuscript.

\section{References}

1) Osono, T.; Y. Oka, S. Watanabe, Y. Numazaki, K. Moriyama, H. Ishida, K. Suzaki, Y. Okami \& H. Umezawa: A new antibiotic, josamycin. I. Isolation and physico-chemical characteristics. J. Antibiotics, Ser A. 20: 173 180, 1967

2) Ömura, S.; Y. Hironaka \& T. Hata: Chemistry of leucomycin. IX. Identification of leucomycin $\mathrm{A}_{3}$ with josamycin. J. Antibiotics 23: 511 513, 1970

3) Ōmura, S.; A. Nakagawa, M. Katagiri, T. Hata, M. Hiramatsu, T. Kimura \& K. Naya: Chemistry of leucomycins. VIII. Absolute configuration of leucomycin and isoleucomycin. Chem. Pharm. Bull. 18: $1501 \sim 1508,1970$

4) Ōmura, S.; M. Katagiri, H. Ogura \& T. Hata: The chemistry of leucomycins. III. Structure and stereochemistry of leucomycin $A_{3}$. Chem. Pharm. Bull. 16: 1181 1186, 1968

5) Regna, P. P.; F. A. Hochstein, R. L. Wagner, Jr. \& R. B. Woodward: Magnamycin. II. Mycarose, an unusual branched-chain desoxysugar from magnamycin. J. Am. Chem. Soc. 75: 4625 4626, 1953

6) Ōmura, S.; M. Katagiri \& T. Hata: The chemistry of leucomycins. VI. Structures of leucomycin $\mathrm{A}_{4}, \mathrm{~A}_{5}, \mathrm{~A}_{6}, \mathrm{~A}_{7}, \mathrm{~A}_{8}$ and $\mathrm{A}_{9}$. J. Antibiotics 21:272 278, 1968

7) Freiberg, L. A.; R. S. Egan \& W. H. Washburn: The synthesis of 9-epi-leucomycin $\mathrm{A}_{3}$. The revised configurational assignment of C-9 in natural leucomycin $A_{3}$. J. Org. Chem. 39: 2474 2475, 1974

8) For example, Wick, W. E. \& D. A. Preston: Biological properties of three 3-heterocyclic-thiomethyl cephalosporin antibiotics. Antimicr. Agent Chemoth. 1: $221 \sim 234,1972$

9) Ömura, S.; H. Ogura \& T. Hata: The chemistry of the leucomycins. I. Partial structure of leucomycin $A_{3}$. Tetrahedron Lett. 1967: 609 613, 1967

10) Ōmura, S.; M. Katagiri, H. Ogura \& T. Hata: The chemistry of leucomycins. I. Partial structure of leucomycin $\mathrm{A}_{3}$. Chem. Pharm. Bull. 15: 1529 1533, 1967

11) Hiramatsu, M.; A. Furusaki, T. Noda, K. Naya, Y. Tomie, I. Nitta, T. Watanabe, T. Take \& J. Abe: The crystal and molecular structure of demycarosyl leucomycin $\mathrm{A}_{3}$ hydrobromide. Bull. Chem. Soc. Jap. 40: 2982,1967

12) Hiramatsu, M.; A. Furusaki, T. Noda, K. Naya, Y. Tomie, I. Nitta, T. Watanabe, T. Take, J. Abe, S. ŌMURA \& T. HATA: The crystal and molecular structure of demycarosyl leucomycin $\mathrm{A}_{3}$ hydrobromide. 
Bull. Chem. Soc. Jap. 43: 1966 1975, 1970

13) Abraham, R. J. \& K. A. McLauchlan: The proton resonance spectra and conformations of prolines. II. The conformations of trans-hydroxy-L-proline and cis-(allo)hydroxy-L-proline in solution. Mol. Phys. 5: 513 523, 1962

14) Abraham, R. J. \& J. S. E. Holker: An investigation by proton magnetic resonance of the conformation of ring $\mathrm{A}$ in some 2-bromo-3-oxo-steroids. J. Chem. Soc. 1963: 806 811, 1963

15) Karplus, M.: Contact electron-spin coupling of nuclear magnetic moments. J. Chem. Phys. 30: 11 15, 1959

16) Karplus, M.: Vicinal proton coupling in nuclear magnetic resonance. J. Am. Chem. Soc. 85: 2870 2871, 1963

17) For example, Paulsen H. \& M. Friedmann: Abhängigkeit der syn-1,3-diaxialen Wechselwirkung von der Art des Substituenten und vom Lösungomittel. Untersuchungen der Konformations-glichgewichte von D-Idopyranose-Derivaten. Chem. Ber. 105: 705 717, 1972 